论 文

\title{
青藏高原古近纪-新近纪地层分区与序列及其 对隆升的响应
}

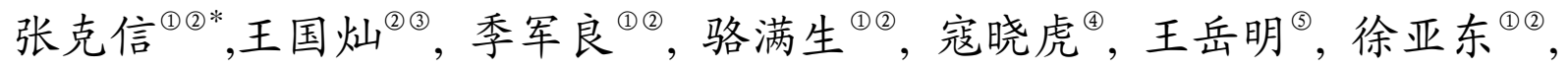

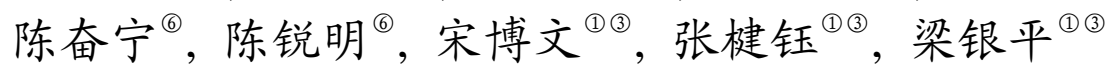

(1) 中国地质大学生物地质与环境地质教育部重点实验室, 武汉 430074;

(2) 中国地质大学地球科学学院, 武汉 430074;

(3) 中国地质大学地质过程与矿产资源国家重点实验室，武汉 430074;

(4) 中国地质大学地质调查研究院, 武汉 430074;

(5) 甘肃省地质矿产勘查开发局, 兰州 730000;

(6) 西安地质矿产研究所, 西安 710054

*E-mail: kx_zhang@cug.edu.cn

收稿日期: 2010-03-17; 接受日期: 2010-06-17

中国地质调查局项目(编号: 1212010610103, 1212010733802)、国家自然科学基金(编号: 40921062, 40830212)和地质过程与矿产资源国家 重点实验室科技部专项经费(编号: MSFGPMR200810)资助

摘要在系统查阅 1996 2008 年中国地质调查局在青藏高原完成的 177 幅 $1: 25$ 万地质填 图和前人已发表的新生代地层资料的基础上, 划分出青藏高原及邻区古近纪-新近纪残留盆 地共 98 个, 归属为南疆-西昆仑、柴达木-祁连-西秦岭、㒸塘-川西、扬子西缘、冈底斯-喜马 拉雅-恒河共 5 个地层区, 进一步细分为 13 个地层分区. 通过对各个地层分区的残留盆地类 型、形成构造背景、各分区内的岩石地层序列及其沉积特征、地层接触关系、时代确定依据 与沉积演化过程的描述, 将青藏高原新生代的隆升及其沉积响应划分为 3 大阶段、8 个亚阶 段: 一是俯冲碰撞隆升阶段(65 34 Ma), 含 3 个亚阶段: (1) 65 56 Ma: 印度与欧亚板块初始 碰撞, 恒河前陆盆地和成都、塔里木压陷盆地形成. (2) 56 45 Ma: 印度与欧亚板块碰撞高峰 期, 高原北部柴达木-可可西里-㒸塘压陷盆地和东北缘的兰州-西宁压陷盆地形成. (3) 45 34 $\mathrm{Ma}$ : 约 $40 \mathrm{Ma}$ 左右藏南新特提斯残留海消亡, 印度与欧亚板块全面完成碰撞; 高原东缘走滑 拉分盆地初始发育. 约 $40 \mathrm{Ma}$ 以来喜马拉雅沉积缺失, 标志喜马拉雅初始隆升; 约 $36 \mathrm{Ma}$ 以 来冈底斯带区域不整合面发育, 标志冈底斯初始隆升。二是陆内汇聚挤压隆升阶段(34 13 $\mathrm{Ma})$, 含 3 个亚阶段: (1) 34 25 Ma: 沿冈底斯分布日贡拉砾岩, 是冈底斯持续隆升的产物. 高 原东北缘出现临夏-循化新的压陷盆地. (2) 25 20 Ma: 沿冈底斯带南缘广布大竹卡组砾岩. 可可西里-沱沱河地区角度不整合面发育和盆地内的古近纪地层抬升变形, 指示可可西里-沱 沦河发生较大幅度隆升. 约 $23 \mathrm{Ma}$ 时塔里木海相沉积结束, 高原及周边不整合面广布, 标志 高原整体隆升. (3) 20 13 Ma: 高原内及周边大型盆地全面发展, 盆内发育持续湖侵充填序 列, 高原及周边出现最大湖泊扩张期; 高原东缘走滑拉分盆地发育进入鼎盛期. 三是陆内均 
衡调整隆升阶段(13 Ma 以来), 含 2 个亚阶段: (1) 13 5 Ma: 喜马拉雅-冈底斯隆升到相当高 度, 使该带因东西向伸展而导致南-北向断陷盆地形成; 约 $8 \mathrm{Ma}$ 左右出现强的构造抬升剥露, $8 \mathrm{Ma}$ 之后高原及邻区大型湖泊进入湖退期. (2) $5 \mathrm{Ma}$ 以来: 高原整体隆升; 高原内和周缘盆 地沉积萎缩. 约 $3.5 \mathrm{Ma}$ 高原周缘堆积巨砾岩.

青藏高原于新生代初全面完成了特提斯洋陆转 换 ${ }^{[1 \sim 3]}$, 成为统一的陆块, 步入陆内演化阶段. 青藏 高原新生代演化的最重大事件是陆内强烈造山作用 与高原强烈地隆升作用 ${ }^{[1,2,4]}$. 新生代高原大规模陆内 造山和隆升驱动的沉积建造, 与前新生代的特提斯 多岛弧盆演化体系的沉积建造大不相同. 因此, 有必 要在盆山耦合与高原隆升-沉积响应的思想指导下, 专门针对青藏高原新生代地层发育进行地层区划和 沉积演变讨论.

本文对青藏高原古近纪-新近纪地层区划的主要 原则是: (1) 分区内所包括的盆地具有大体一致的构 造演化背景和形成机制; (2) 分区内所包括的盆地具 有大体一致的构造-地貌景观; (3) 分区内所包括的盆 地具有相对一致的沉积充填序列和大体相近的沉积 环境演化过程. 以上述划分原则为指导, 在系统查阅 1996 2008 年中国地质调查局在青藏高原及邻区完成 的 177 幅 1:25 万地质填图中新生代地层资料, 并结合 前人已发表成果 ${ }^{[1 \sim 35]}$ 的基础上, 划分出青藏高原及邻 区古近纪-新近纪残留盆地共 98 个(图 1), 归属为南疆西昆仑(I)、柴达木-祁连-西秦岭(II)、芫塘-川西(III)、 扬子西缘(IV)、冈底斯-喜马拉雅-恒河(V)共 5 个地层 区, 进一步细分为 13 个地层分区(图 1). 本文将图 1 中的 98 个盆地称之为残留盆地, 是因为新近纪晚期 以来的青藏高原隆升成山作用, 以大规模的山体隆 升为特征 $^{[4,34,35]}$, 其结果将一部分古近纪-新近纪沉积 盆地抬升到山顶, 其沉积物大都遭受了剥蚀, 使现存 盆地的沉积记录残缺不全, 此类盆地被称之为残留 盆地 ${ }^{[36]}$. 本文图 2 所列地层单位均为中国地质调查局 1996 2008 年期间 1:25 万地质填图中使用过的岩石 地层单位, 凡地质填图中没使用过的地层单位本文 均未作为正式的“组级”岩石地层单位启用.

\section{1 南疆-西昆仑地层区沉积特征与演变}

南疆-西昆仑地层区根据盆地类型和盆地沉积充
填序列特征(图 2), 划分为塔里木地层分区和西昆仑喀喇昆仑地层分区(图 1,2).

\section{1 塔里木地层分区}

包含塔里木盆地, 为挤压背景下的构造挠曲压 陷盆地. 盆地新生代沉积与下伏白严纪海相地层为 连续沉积. 古近纪盆地为新特提斯海的一部分, 以半 封闭的海湾滨浅海沉积为主, 从老至新岩石地层单 位依次是阿尔塔什组、齐姆根组、卡拉塔尔组、乌拉 根组和巴什布拉克组, 各组间均呈整合接触(图 2). 阿尔塔什组 $\left(\mathrm{E}_{1} a\right.$, 厚 100 375 m) 为白色巨厚层状石膏 夹灰色、灰白色灰岩、白云岩、膏化白云岩及黄绿色 薄层状泥岩, 为滨海咸化潟湖相沉积. $\mathrm{E}_{1} a$ 含古新世 化石组合: 有孔虫Quinqueloculia; 介形虫Cytheridea hashiensis, Heplocyeridea viriosa ${ }^{[5]}$. 齐姆根组 $\left(\mathrm{E}_{1-2} q\right.$, 厚 51 126 m) 为灰绿、灰色泥岩夹砂岩和灰质介壳层, 底部为浅灰色生屑灰岩和灰质白云岩, 区域上相变 为褐红色膏泥岩, 为咸化的滨浅海沉积. 含古新世晚 期-始新世早期化石组合: 有孔虫SphooplectamminaDiscorbis-Nonionellina组合 ${ }^{[6]}$; 介形虫Costa subscalaris, Cytheridea ahunda, Eocytheropteron kalickyi, Hermanites suzakensis, Krithe rutoti, Trachyleberis $s c a b r a$ 等 $^{[5]}$. 卡拉塔尔组 $\left(\mathrm{E}_{2} k\right.$, 厚 38 276 m) 为灰色生 物屑泥晶灰岩、鲕粒灰岩、牡蚛介壳灰岩, 下部夹少 量灰绿色泥岩, 为滨浅海沉积, 含始新世中期化石组 合: 有孔虫Nonion laevis, Pararotalia mimicusa, Asterigerina bararotalia, Anomalina sp., Cibicides sp., Melonis sp., Quinqueloculina sp.等 ${ }^{[6]}$; 介形虫Cytheridea, Cytherura, Loxoconcha, Schizocythere, Trachyleberis 等 ${ }^{[5]}$. 乌拉根组 $\left(\mathrm{E}_{2} w\right.$, 厚 $\left.53 \sim 64 \mathrm{~m}\right)$ 为灰绿色泥 岩、生屑泥晶灰岩, 上部夹暗红色泥岩和少量细砂岩, 为开阔碳酸盐台地-滨岸沉积, 含始新世晚期化石组 合：双壳类Kokanostrea koksnensis, Felemingostrea 


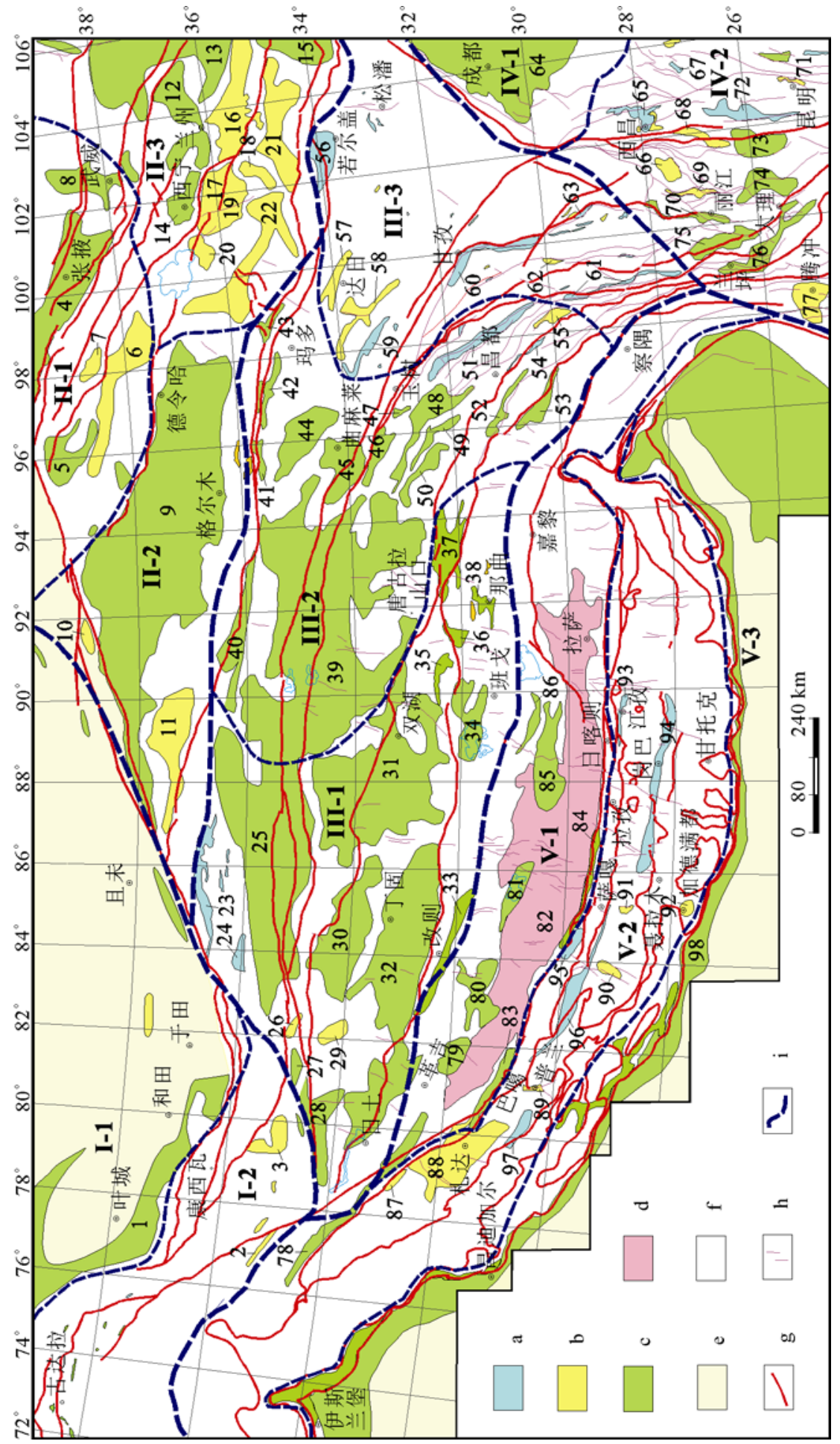

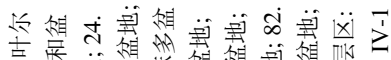

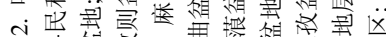

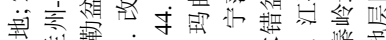

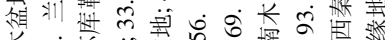

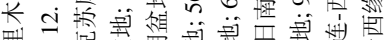

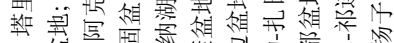

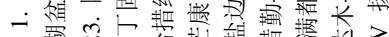

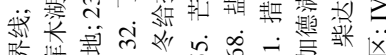

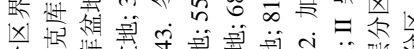

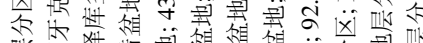

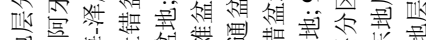

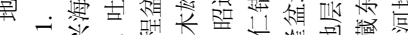

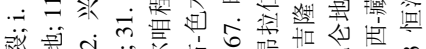

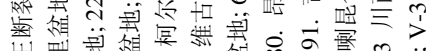

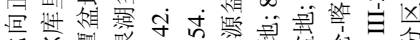

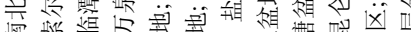

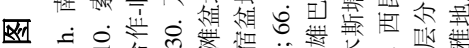

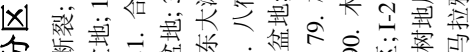

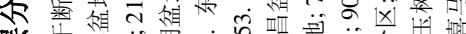

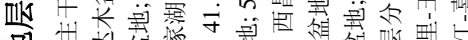

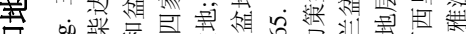

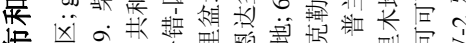

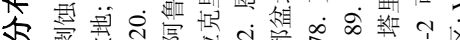

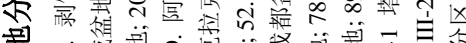

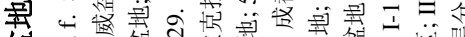

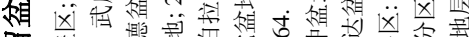

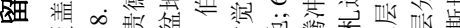

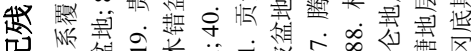

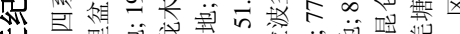

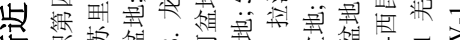

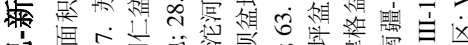

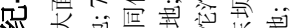

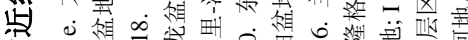

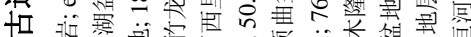

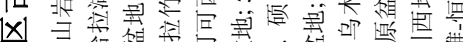

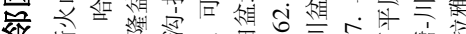

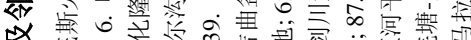

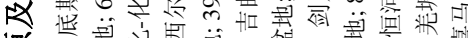

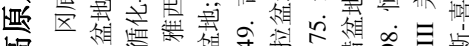

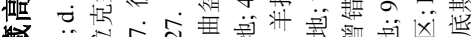

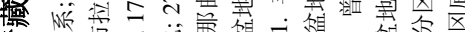

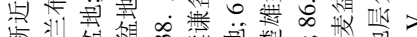

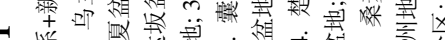

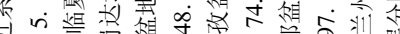

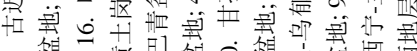

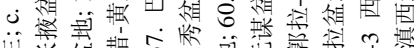

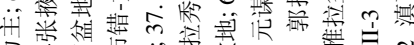

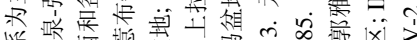

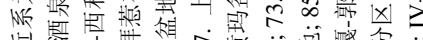

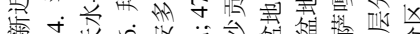

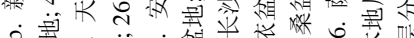

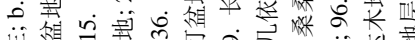

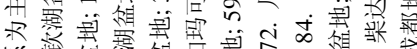

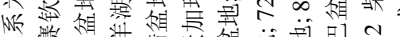

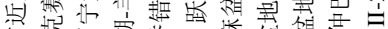

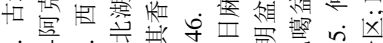

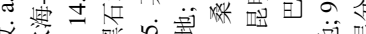

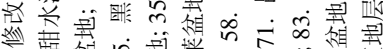

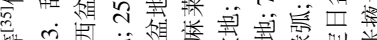

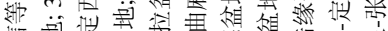

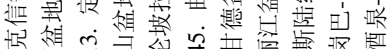

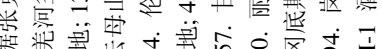




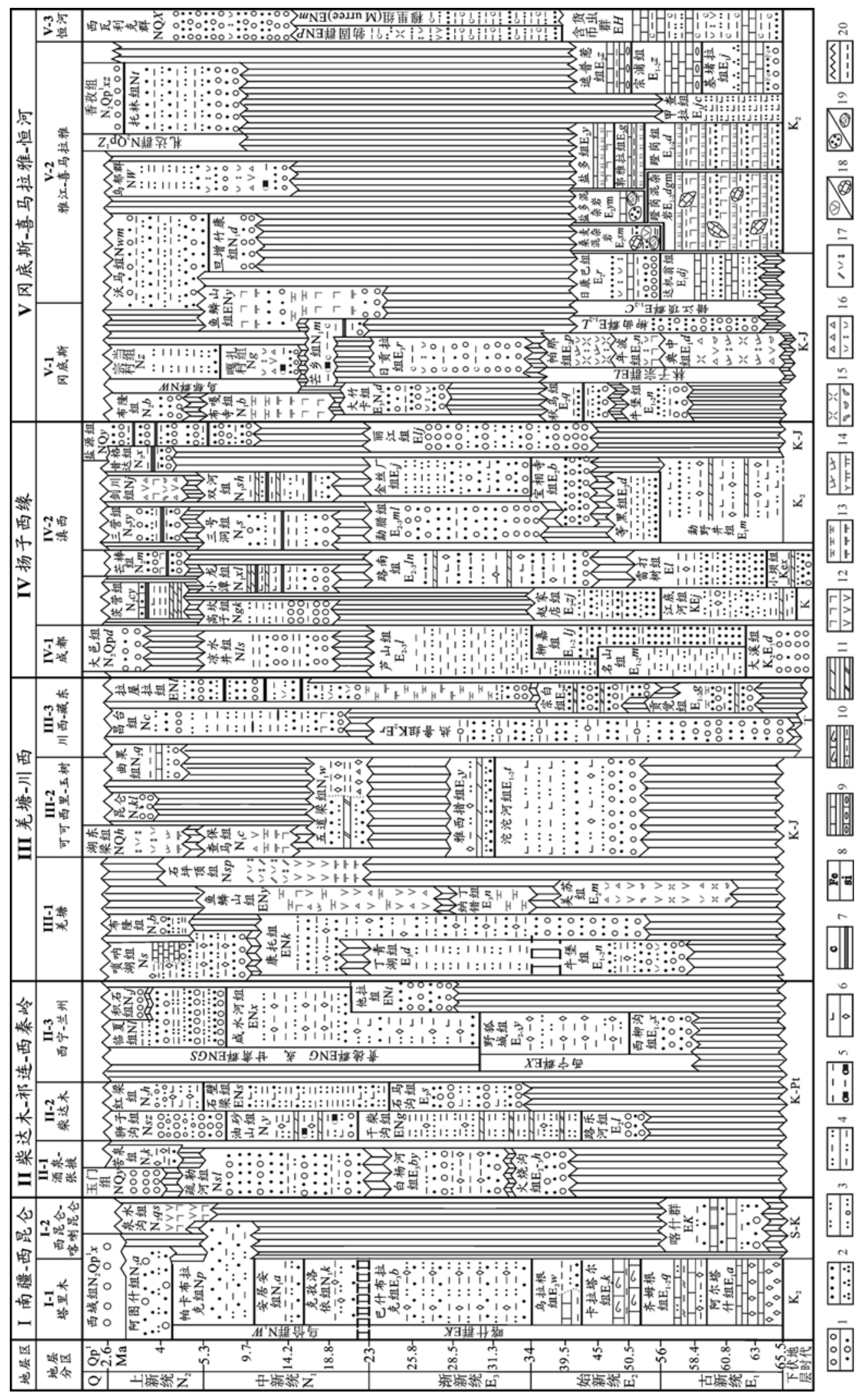


yeagisarica, Ostrea (Ostrea) ulugqatics 等 ${ }^{1)}$; 有孔虫 Nonion-Anom-linoides-Cibicides 组 合 ${ }^{[6]}$; 介形 虫 Bradleya sinensis, Costa decorosa, Cytherella ventriconvexa, Cytherilloidea vallaris, Cytheridea tonsa, Eocytheropteron wetherelli, Pterygocythereis cornuta 等 ${ }^{[5]}$. 巴什布拉克组 $\left(\mathrm{E}_{3} b\right.$, 厚 $274 \sim 527 \mathrm{~m}$ ) 为紫红、红 灰色泥岩、细砂岩、钻质粉砂岩夹少量石膏薄层, 上 部夹灰绿色粉砂岩和泥岩, 底部为厚数十米的石膏 层, 为海湾-潟湖相沉积. 含渐新世化石组合: 有孔虫 Upper Nonion-Cibieides 组合和Cibicidoides动物群 ${ }^{[6]}$; 介形虫 Clithrocytheridea scrobiculata Cytheretta virguleata, Haplocytheridea angusta, Ranocythereis laudata, Schuleridea eximia, Trachyleberis pachyodonta等 ${ }^{[5]}$.

塔里木盆地在渐新世末期由海相转换为陆相湖 盆, 古近系与新近系之间为区域性盆地构造反转面 所分割, 表现为平行不整合-微角度不整合面.

塔里木盆地新近系岩石地层单位从老至新依次 是克孜洛依组、安居安组、帕卡布拉克组、阿图什组 和西域组, 各组间均呈整合接触(图 2). 中新世早期 偶受西去的新特提斯海的海泛影响, 中新世晚期完 全脱离海泛, 进入内陆大型湖盆至湖盆消亡期沉积 阶段.

克孜洛依组 $\left(\mathrm{N}_{1} k\right.$, 厚 416 442 m)下部为灰红、紫 灰、棕红色细砂岩、钻质粉砂岩、钻质泥岩、暗红色 泥岩夹少量灰绿色粉砂岩; 上部为细砂岩与钙质粉 砂岩互层, 夹薄层石亳, 为近海平原咸化滨浅湖沉积; 含中新世早期化石组合：介形虫 Cyprideis, Daruwinula, Hemicyprideis, Hemicyprinotus, Mediocypris 等 ${ }^{[5]}$ 和有孔虫 Cypides littoralis ${ }^{[6]}$. 安居安组 $\left(\mathrm{N}_{1} a\right.$, 厚 912 937 m) 为灰绿、灰红色细砂岩与灰绿、 棕红色粉砂岩互层, 底部为厚达数十米的绿灰色厚 层状细砂岩, 为陆源碎屑滨浅湖沉积, 含中新世中期 化石组合: 有孔虫Ammonia组合; 介形虫 Cyprideis, Candoniella, Darwinula, Llyocypris, Limnocythere 等 ${ }^{[5] 1)}$. 帕卡布拉克组 $(\mathrm{N} p$, 厚 $1266 \mathrm{~m})$ 下部为灰色复 成分砾岩与灰红色细砂岩不等厚互层; 中部为灰红 色细砂岩夹含砾粗砂岩及少量暗红、灰绿色薄层泥岩
夹膏泥岩和膏盐层; 上部为细砂岩与暗红、紫红色泥 岩互层夹透镜状砾岩及少量灰绿色泥岩, 夹膏泥岩 和膏盐层, 为咸水滨浅湖沉积, 含中新世晚期化石组 合: 有孔虫Ammonia honyaensis, A. hatatatensis, A. beccarii等 ${ }^{1)}$; 介形虫Cyprideis punctillata, Ilyocypris evidens 等 ${ }^{[5]}$. 阿图什组 $\left(\mathrm{N}_{2} a\right.$, 厚 595 2042 m) 为灰、褐 灰色复成分砾岩与浅红色细砂岩互层夹泥岩、粉砂岩 和少量亳泥岩和薄层亳盐层, 为山麓河流-三角洲-微 咸水滨浅湖沉积; 含上新世介形虫 Candoniella kasachstanica, Cyclocypris regularis, Cypridopsis vidua, Eucypris notabilis 等 ${ }^{[5]}$. 西域组 $\left(\mathrm{N}_{2} \mathrm{Qp}^{1} x\right.$, 厚 $317 \sim 4568 \mathrm{~m})$ 为褐灰色、灰色复成分砾岩夹紫红、灰 红色砂岩或透镜体, 为山前冲洪积扇沉积, 古地磁年 龄为 $3.5 \sim 1.8 \mathrm{Ma}^{[37]}$, 为上新世晚期-早更新世.

\section{2 西昆仑-喀喇昆仑地层分区}

主要包含 2 个盆地, 分别是叶尔芫河和甜水海阿克赛钦湖盆地(图 1), 为中新世随着山脉急剧隆升 形成的山间拗陷-断陷盆地. 盆地内堆积了以紫红色 和灰色砾岩、砂岩为主的山麓河流和冲洪积扇沉积 (帕卡布拉克组(厚 $583 \mathrm{~m}$ ) 和阿图什组(厚 50 272 m)) (图 2). 在泉水沟一带还发育了一套中新世末期至上 新世板内构造环境的基性-酸性火山岩(泉水沟组)(图 2), 在泉水沟玄武岩中获 $5.84 \mathrm{Ma}$ 的 K-Ar法年龄和 $(8.1 \pm 0.1) \mathrm{Ma}$ 的全岩 $\mathrm{Rb}-\mathrm{Sr}$ 等时线年龄 ${ }^{2)}$. 潘裕生等 ${ }^{[38]}$ 用K-Ar法获 3.3 6.6 Ma的年龄. 古近纪地层(喀什群, 厚 $2636 \mathrm{~m}$ ) 在该区分布零星, 现仅少量分布在古达拉 一带和龙木错北侧与蚂蟥山南侧一带(图 1). 推测该 分区在古近纪时部分地区可能为低缓的隆起区, 部 分地区为滨海海湾-潟湖环境; 新近纪经历了强烈隆 起, 使绝大部分古近纪沉积全被剥蚀.

\section{2 柴达木-祁连-西秦岭地层区沉积特征 与演变}

柴达木-祁连-西秦岭地层区根据盆地类型和盆 地沉积充填序列特征(图 2), 划分为酒泉-张掖地层分 区，柴达木地层分区和兰州-西宁地层分区(图 1,2).

1) 河南省地质调查院. 新疆 $1: 25$ 万英吉沙县幅区域地质调查报告. 2005

2) 陕西省地质调查院. 新疆 1:25 万阿克赛钦湖幅区域地质调查报告. 2006 


\section{1 酒泉-张掖地层分区}

包含 5 个盆地, 为酒泉-张掖、乌兰布拉克、哈拉 湖、苏里和武威盆地(图 1). 本文以酒泉-张掖盆地为 代表简述其沉积演化. 酒泉-张掖盆地为受阿尔金走 滑断裂和北祁连山前逆冲断裂控制的挤压背景下的 构造挠曲压陷盆地. 古新世-始新世早期, 该区处于 隆升剥蚀状态, 无沉积. 始新世晚期(约 $40.5 \mathrm{Ma}$ ) 祁 连断裂和阿尔金走滑断裂分支的宽滩山-龙首山南缘 断裂逆冲, 使酒泉-张掖一带开始拗陷, 盆地开始孕 育. 其后盆地扩大, 在北部和西部发育了山麓洪积扇河流-三角洲相沉积, 称火烧沟组 $\left(\mathrm{E}_{2-3} h\right.$, 厚 250 1000 m) (图 2). $E_{2-3} h$ 角度不整合于白严系赤金堡组之上, 其岩性从下向上为杂色砾岩-深棕红、桔红、灰白色 砂岩、泥岩夹砾岩、含砾砂岩-棕红色泥岩夹灰白、 草黄绿色砂岩和细砾岩-桔红色细砾岩, 含砾砂岩、砂 岩和泥质砂岩, 磁性地层年龄为 $40.5 \sim 33 \mathrm{Ma}^{[39]}$. 渐新 世(约33 31 Ma)酒泉盆地再次压陷接受沉积, 沉积主 体为扇三角洲-浅湖相以及盐湖夹三角洲相沉积, 称 白杨河组 $\left(\mathrm{E}_{3} b\right.$, 厚 454 929 m), 与下伏火烧沟组呈角 度不整合, 主要岩性从下向上为桔红、棕红色含砾砂 岩、砂岩和棕红色泥岩互层夹石膏层-暗棕红色泥岩 夹天青色砂岩和石亳层-棕红色泥岩、砂岩和砾质砂 岩互层, 磁性地层年龄为 31 24 $\mathrm{Ma}^{[39]}$. 渐新世晚期 强烈的构造活动, 导致酒泉-张掖盆地的古近纪地层 变形和剥蚀, 其后沉积的新近纪地层(称疏勒河组和 苦泉组)不整合于古近纪地层之上. 疏勒河组和苦泉 组以辫状河-浅湖夹扇三角洲-半深湖相沉积为主, 代 表盆地沉积范围扩大, 盆地发展到鼎盛阶段. 疏勒河 组 $(\mathrm{Ns} l$, 厚 1300 1700 m)下部为灰白色厚层砂岩、泥 岩夹泥灰岩, 底部为灰白色砾质砂岩, 中部为棕红色 砂质泥岩、砂岩和黄色、灰色砾岩互层, 上部为灰黄 色砾岩、砂岩夹棕红色砂岩和黄色砂质泥岩, 磁性地 层年龄为 $23 \sim 4.9 \mathrm{Ma}^{[39,40]}$. 苦泉组 $\left(\mathrm{N}_{2} k\right.$, 厚 $\left.246 \mathrm{~m}\right)$ 为 桔红、桔黄色粉砂质泥岩夹杂色泥岩、砂岩、砾岩和 石亳, 局部夹灰岩和盐类矿产, 为咸化湖泊沉积, 含 上新世腹足类Pseudophysa cf. grabaui 等 ${ }^{[14]}$. 中新世 晚期以后, 盆地逐渐萎缩, 沉积物由前期以湖相为主 逐渐变为以洪积扇和河流相为主, 称玉门组 (NQy, 厚 $>750 \mathrm{~m}$ ), 主体由大套的砂泥质砾岩层、砾岩夹砂 泥质条带组成, 磁性地层年龄为 3.66 0.93 $\mathrm{Ma}^{[40]}$.

\section{2 柴达木地层分区}

包含 3 个盆地, 分别为柴达木、索尔库里和阿牙 克库木湖盆地(图 1).

柴达木盆地的演化受祁连山构造带、阿尔金构造 带和东昆仑构造带的共同影响(图 1). 古新世为无沉 积的隆起区. 始新世早期初始拗陷, 自约 $53.5 \mathrm{Ma}$ 开 始接受与下伏地层不整合的路乐河组 $\left(\mathrm{E}_{2} l\right.$, 厚 300 1200 m) 粗碎屑沉积(图 2), 总体沉积面积较小. $\mathrm{E}_{2} l$ 主要为紫红色砾岩与砂岩互层夹粉砂岩和泥岩, 具下部粗、中部细、上部又变粗的沉积旋回特征, 反 映出早期以山麓洪积扇-河流相为主、中期为滨浅湖三角洲前缘、晚期为三角洲平原沉积, 磁性地层年龄 为 53.47 43.8 $\mathrm{Ma}^{[39]}$. 约 43.8 42.9 Ma时期的构造活 动造成盆地北缘路乐河一带沉积间断 ${ }^{[39]}$, 之后从始 新世晚期开始, 盆地更大范围拗陷. 渐新世-中新世 早期为盆地稳定发展期, 盆地整体持续下降, 形成比 路乐河组分布范围更广、几乎遍及全盆地的干柴沟组 和油砂山组的细碎屑沉积, 沉积厚度巨大. 干柴沟组 $(\mathrm{EN} g$, 厚 800 $3300 \mathrm{~m}$ ) 分为上下两段. 下段(或称下 干柴沟组)在盆地西部以棕红色泥岩、泥质粉砂岩夹 砂岩为主, 东部则为黄绿色、灰白色砾岩、砾状砂岩 及紫红色砂质泥岩; 上段(或称上干柴沟组)在盆地西 部以灰色、深灰色、棕红色泥岩夹钙质泥岩、泥灰岩 及粉砂岩条带为主, 东部为巨厚层黄绿色砂岩与棕 红、棕灰色砂质泥岩不等厚互层. 上、下段均夹薄层 膏泥岩和膏盐层, 含介形虫 ${ }^{[41]}$ 、轮藻和腹足类 ${ }^{[42]}$, 磁 性地层年龄为 $22 \sim 42.9 \mathrm{Ma}^{[39]}$. 油砂山组 $\left(\mathrm{N}_{1} y\right.$, 厚 550 3300 m)也分为上下两段. 下段(或称下油砂山组) 在盆地西部以棕红色砂质泥岩与灰色泥质粉砂岩为 主, 上部夹砾岩及较多的泥灰岩、疮㾑灰岩和杂色泥 岩; 盆地东部以黄绿色砂岩、粉砂岩、泥质粉砂岩和 粉砂质泥岩为主夹杂色泥岩、泥灰岩、薄层膏泥岩和 膏盐层. 上段(或称上油砂山组)在盆地西部以灰棕、 浅棕黄色砂岩、泥岩与灰色、棕灰色含砾砂岩互层为 主; 东部以黄色、黄褐色、棕灰色泥岩、砂质泥岩和 泥质粉砂岩为主夹灰色、灰白色粉砂岩、砂岩和含砾 砂岩、薄层膏泥岩和膏盐层. $\mathrm{N}_{1} y$ 含介形虫 ${ }^{[41]}$ 和三趾马 化石 Hipparion cf. H. chiai, Hipparion weihoense, Hipparion teilhardi ${ }^{[43]} . \mathrm{N}_{1} y$ 磁性地层年龄为 $22 \sim 8.2$ $\mathrm{Ma}^{[39]}$. 中新世晚期(约 $8.2 \mathrm{Ma}$ 以后)-上新世, 盆地西 部逐渐抬升, 沉积中心逐渐向东部迁移, 盆地沉积面 
积缩小, 接受粗碎屑的狮子沟组 $(\mathrm{N} s z$, 厚 300 1300 m) 沉积, 盆地演化进入萎缩和消亡的发展阶段. 狮子沟 组在盆地西部以灰绿、灰色泥岩为主夹粉砂岩、砂岩、 砾岩、石膏及泥灰岩, 盆地东部以灰色、黄灰色和土 黄色砾岩、含砾砂岩和粗砂岩为主, 含介形虫 ${ }^{[41]}$ 、轮 藻和腹足 ${ }^{[42]}$, 磁性地层年龄为 $8.2 \sim 2.5 \mathrm{Ma}^{[39]} . \mathrm{N} s z$ 与 下伏油砂山组在盆地中心为连续沉积, 在盆地边缘 为不整合接触. $2.6 \mathrm{Ma}$ 以后盆地进入山间盆地阶段, 湖盆沉降中心东移至盆地东部三湖凹陷地区, 彻底 改变了柴达木古湖盆的全貌 ${ }^{[39]}$.

索尔库里盆地位于阿尔金山中段，是阿尔金山 断裂带中的一个山间盆地 ${ }^{[4]}$, 为阿尔金走滑断裂控 制下的拉分盆地(图 1). 索尔库里地区主体在 $17.7 \mathrm{Ma}$ 前处于隆起剥蚀, 没有接受沉积, 只在北部及东部与 柴达木盆地贯通处接受了少量沉积. 约 $17.7 \mathrm{Ma}$ 开始 下陷, 盆地主体开始接受沉积, 发育了一套以洪积扇 相 - 滨浅湖相为主的沉积地层 (油砂山组下段). 14.2 9.88 Ma期间, 是盆地的主要发展期, 盆地广泛 接受沉积, 以大套稳定的湖相沉积为主 (油砂山组上 段). 大约从 $9.88 \mathrm{Ma}$ 以后, 盆地发展进入萎缩期, 沉 积环境发生重大改变, 水体变浅, 由前期半深湖环境 转变不稳定的水下扇三角洲-洪积扇相, 沉积了巨厚 的粗碎屑沉积 (狮子沟组) ${ }^{[44]}$.

阿牙克库木湖盆地夹持在东昆仑造山带与阿尔 金造山带之间的三角地带, 东邻柴达木盆地(图 1), 是受周缘断裂控制的压性构造环境下的断拗盆地. 古新世-始新世期间, 盆地主体处于隆升剥蚀状态, 没有接受沉积. 渐新世为盆地初始断拗阶段, 在盆地 南部接受了石马沟组下段冲积扇-河流相沉积(图 2); 随着盆地的稳定沉降, 接着沉积了石马沟组上段三 角洲相沉积和石壁梁组下段湖相沉积. 石马沟组 $\left(\mathrm{E}_{3} s\right.$, 厚 $3171 \mathrm{~m}$ )下段为浅灰、浅褐色复成份砂岩、含砾粗 砂岩与褐红色钙质粉砂岩不等厚互层夹褐红色钙质 粉砂质泥岩; 上段为褐红色铻质岩屑砂岩与褐红色 钙质粉砂质泥岩不等厚互层, 夹杂色含砾粗砂岩和 砾岩透镜体. $\mathrm{E}_{3} s$ 含介形虫Eucypris paraserrata, E. mutilis 等和孢粉 ${ }^{3)}$, 据化石组合为渐新世. 中新世盆 地范围不断扩大并稳定发展, 在盆地边缘接受了石 壁梁组三角洲相沉积, 向盆地中心为石壁梁组湖相 沉积, 总体上反映为粒度较细、成熟度较高的稳定型
沉积建造. 石壁梁组 $\left(\mathrm{N}_{1} s\right.$, 厚 $\left.4121 \mathrm{~m}\right)$ 下段为褐红、灰 绿色粉砂岩、钙质粉砂质砾岩; 上段为紫红色钙质粉 砂岩与钙质粉砂质泥岩互层夹厚层块状中-细砂岩. $\mathrm{N}_{1} s$ 含介形虫：Candoniella suzini, C. folicaceus, Eucypris flexilis等和孢粉 ${ }^{3}$, 据化石组合为中新世. 上 新世盆地进入萎缩阶段, 接受红梁组沉积. 红梁组 $\left(\mathrm{N}_{2} h\right.$, 厚 $\left.3021 \mathrm{~m}\right)$ 为砖红色砂岩与粉砂质泥岩、泥岩、 膏泥岩不等厚互层夹杂色砂砾岩和夹膏盐沉积, 含 介形虫Candoniella aucta, Ilyocypris kitons 等和腹足类 Corbicula largillieri, Gyraulus coretus 等 ${ }^{3)}$ ，据化石组 合为上新世. 随着盆地逐渐萎缩, 沉积范围缩小, 湖 水逐渐变浅, 红梁组在盆地中心出现了咸水湖相膏 盐沉积, 在盆地边缘为冲积扇、河流到三角洲粗碎屑 沉积, 表现为湖退沉积组合. 该阶段形成了石膏、石 盐等丰富的蒸发盐类矿产. 上新世末, 受构造隆升影 响, 全区最终上升为陆.

\section{3 西宁-兰州地层分区}

包含 11 个盆地，分别为兰州-民和、定西、西宁、 天水-西和、临夏、循化-化隆、同仁、贵德、共和、 合作-临潭和兴海-泽库盆地(图 1). 本文以兰州-民和 盆地、西宁盆地和循化-化隆盆地为代表，简述其沉积 演变.

兰州-民和盆地位于青藏高原东北缘，祁连造山 带东段(图 1). 古新世期间, 盆地处于隆升剥蚀状态. 约 $58 \mathrm{Ma}$ 的古新世未期, 盆地开始下陷, 盆地开始接 受沉积. 58 51 Ma沉积西柳沟组 $\left(\mathrm{E}_{1-2} x\right.$, 厚 $\left.>152 \mathrm{~m}\right)$, 盆地边缘为冲洪积扇砖红色砾、砂岩组合, 向盆地中 部相变为砖红色块状砂岩夹泥岩为主的三角洲至湖 相沉积. $\mathrm{E}_{1-2} x$ 磁性地层年龄为 $58 \sim 51 \mathrm{Ma}^{[45]} .51 \sim 4.48$ $\mathrm{Ma}$ 期间盆地沉积范围扩大, 盆地广泛接受大套稳定 的咸化湖相沉积(野狐城组和咸水河组). 大约 4.48 Ma以后，盆地进入萎缩消亡期，前期的咸化湖环境 消亡，仅在盆地边缘发育了少量冲洪积扇的粗碎屑 沉积. 野狐城组 $\left(\mathrm{E}_{2-3} y\right.$, 厚 $\left.440 \mathrm{~m}\right)$ 为紫红色泥岩、膏泥 岩、粉砂岩与砂岩互层夹石膏层, 磁性地层年龄为 51 31.5 $\mathrm{Ma}^{[45]}$, 含哺乳类化石Metexallerix gaolanshanensis, Tataromys grangeri, T. suni, T.sp., Tataromys cf. gracilidens, Tsaganomys altaicus ${ }^{[46]}$. 咸水河 组 $(\mathrm{EN} x$, 厚 $738 \mathrm{~m})$ 分下、中和上三个岩性段：下段下

3) 陕西省地质调查院. 新疆 1:25 万阿克赛钦湖幅区域地质调查报告. 2006 
部为红色泥岩夹黄色厚层砂岩, 底部为褐黄色、灰绿 色砂岩夹细砾岩; 下段中-上部以泥岩为主夹少量细 砂岩层含石膏脉; 中段下部为白色厚层状砂岩, 中上 部以红色泥岩为主夹多层白色、灰绿色砂岩, 局部夹 泥灰岩层, 见介壳类生物碎屑; 上段为浅黄色砂砾岩 与浅棕色砂质泥岩. $\mathrm{EN} x$ 磁性地层年龄为 $31.5 \sim 15$

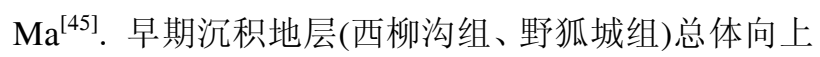
变细、向盆边缘粗碎屑岩增多岩层增厚的旋回性加 积-退积型层序, 反映出盆地基底均匀沉降, 可容空 间逐渐扩大的现象, 表明控盆断裂(如雾宿山北缘山 前断裂)具有多期同生断裂的活动特点, 并与青藏高 原东北缘阶段性隆升耦合; 晚期沉积地层(咸水河组) 具有总体向上变粗、向盆边粗碎屑岩增多岩层增厚的 旋回性加积-进积型层序特征, 反映出盆地可容空间 逐渐萎缩的现象.

西宁盆地被青藏高原东北缘的青海南山、大坂山 和拉脊山所围限(图 1). 古新世-始新世早期, 盆地主 体处于隆升剥蚀状态. 约 52 50 Ma时盆地开始下陷, 盆地主体接受冲洪积扇、扇三角洲-滨浅湖沉积(西柳 沟组, $\mathrm{E}_{1-2} x$, 厚度 $>50 \mathrm{~m}$ ). 西柳沟组在西宁盆地通常 称祁家川组 $\left(\mathrm{E}_{2} q j\right)$, 相当于西宁群 $(\mathrm{E} X)$ 下部. $\mathrm{E}_{1-2} x$ 在盆 地边缘为含砾砂岩与砂岩互层; 盆地中部底部为含 砾细-粗砂岩, 中上部为泥岩、石膏岩. 盆地中部以滨 浅湖沉积为主, 周缘为冲洪积扇-扇三角洲沉积, 磁 性地层年龄为 $52.5 \sim 50 \mathrm{Ma}^{[47]}$. 始新世中期至中新世, 盆地沉积范围扩大, 盆地广泛接受大套富含膏盐层 的咸化湖相细碎屑沉积(野狐城组和咸水河组). 野狐 城组 $\left(\mathrm{E}_{2-3} y\right)$ 在西宁盆地通常称洪沟组和马哈拉沟组, 相当于西宁群 $(\mathrm{E} X)$ 上部. 本文将洪沟组和马哈拉沟 组降组为段, 将其归入野狐城组 $\left(\mathrm{E}_{2-3} y\right)$, 分两段, 下 段为洪沟段, 上段为马哈拉沟段. 洪沟段 $\left(\mathrm{E}_{2} h g\right.$, 厚 $150 \mathrm{~m}$ ) 在盆地边缘为含砾砂岩、砂岩与含石亳砂岩, 盆地中部为泥岩夹石膏, 磁性地层年龄为 $50 \sim 41.5$ $\mathrm{Ma}^{[47]}$. 马哈拉沟段 $(\mathrm{E} m h$, 厚 $290 \mathrm{~m}$ ) 在盆地边缘为膏 泥岩、泥岩夹石膏、砂砾岩与泥岩互层, 盆地中部为 泥岩与石膏互层. E $m h$ 由盆地中心向边缘可分为咸水 深湖沉积-咸水浅湖沉积-滨湖相沉积-河流及冲洪积 扇沉积. $\mathrm{E} m h$ 磁性地层年龄为 41.5 30 $\mathrm{Ma}^{[47]}$. 本文使 用的咸水河组为广义的咸水河组 $(\mathrm{EN} x)$, 在西宁盆地 通常自下而上称谢家组、车头沟组和(狭义的)咸水河 组. 本文将西宁盆地的谢家组、车头沟组和(狭义的) 咸水河组降组为段, 分别称之为咸水河组下段(相当
于“谢家组”)、中段(相当于“车头沟组”)和上段(相当于 狭义的“咸水河组”). EN $x$ 下段(厚 $109.9 \mathrm{~m}$ )下部为粉砂 质泥岩与泥质石膏岩不等厚互层, 底部夹砂砾岩凸 镜体, 上部为棕黄色含粉砂钙质泥岩, 属咸水至淡水 滨浅湖相沉积, 含哺乳动物Sinlagomys pachygnathus, Aflantoxerus, Eucricetodon youngi, Parasminthus xiningensis, $P$. huangshiensis, P. ajeensis, Tataromys suni, Tachyoryctoides roronorensis, Diacerarherium sp., Sinopalaeoceros xiejiaensis 等 $^{[8]}$. EN $x$ 下段磁性地 层年龄为 30 23 $\mathrm{Ma}^{[47]}$. $\mathrm{EN} x$ 中段(厚 $61.1 \mathrm{~m}$ )下部为石 亳质石英砂岩与含钙粉砂质泥岩不等厚互层, 上部 为含粉砂钙质泥岩夹石膏质泥岩, 属咸水滨浅相沉 积, 含哺乳动物 Megacricetodon sinensis, Heterosminthes orientalis, Palaeomeryx sp., Stephanocemas sp., Megacricetodon cf. Sinensis 等 ${ }^{[48]}$. EN $x$ 中段磁性地层 年龄为 $23 \sim 18 \mathrm{Ma}^{[47]}$. 上段(厚 $171 \mathrm{~m}$ ) 为棕黄色钙质泥 岩和砂岩夹泥灰岩和细砾岩, 以滨浅湖沉积为主, 盆地 边缘相变为河流相, 含哺乳动物 Gomphotherium wimani, G. connexus, Stephanocemas chinghaiensis, Alloptox chinghaiensis, Plesiodipus leei, Micromeryx sp., Bunolistriodon minheensis 等 $^{[48]}$. EN $x$ 上段底部的古地 磁年龄为 $18 \mathrm{Ma}^{[47]}$. 从中新世晚期开始, 盆地进入萎 缩消亡期, 前期的咸化湖环境被向上变粗的河流相山麓相堆积所替代, 被称为临夏组 $(\mathrm{N} l$, 厚 $90.3 \mathrm{~m}) . \mathrm{N} l$ 为灰色中至粗粒砂岩与棕黄色砂质泥岩互层, 含哺 乳动物 Hipparion cf. coelophyes, H. sp., Chleuastochoerus stehlini, Gazella sp. 等 ${ }^{[48]}$, 时代为中新世晚期上新世.

循化-化隆盆地向东与同时期的临夏盆地相连. 总体上构成向东张开的压陷盆地 ${ }^{\left[{ }^{[9]}\right.}$ (图 1). 该盆地的 岩石地层序列从老至新为他拉组、咸水河组、临夏组 和积石组(图 2). 他拉组 (EN $t$, 厚度 $>124.1 \mathrm{~m}$ ) 与下伏 地层角度不整合接触, 以红褐色厚层状砾岩、含砾砂 岩为主, 上部夹紫红色泥岩, 属河流-冲积扇相沉积. 咸水河组 $(\mathrm{EN} x$, 厚 $618.5 \mathrm{~m}$ ) 自下而上划分为中庄段 $\left(\mathrm{E}_{3} \mathrm{~N}_{1} c z\right)$ 、上庄段 $\left(\mathrm{N}_{1} s z\right)$ 和东乡段 $\left(\mathrm{N}_{1} d\right)$. 中庄段(厚 $145.5 \mathrm{~m}$ )下部为紫红色含砾中-细粒砂岩与紫红色含 细砾粉砂质泥岩夹浅灰色砾岩, 上部为红褐色、紫红 色粉砂质泥岩、泥质粉砂岩, 局部见粗砂岩和细砾岩 夹层, 含少量薄层状石膏夹层. 上庄段(厚 $138.2 \mathrm{~m}$ ) 为 紫红色、褐红色粉砂岩、泥质粉砂岩与粉砂质泥岩互 层夹亳泥岩与少量薄层石膏. 东乡段(厚 $334.8 \mathrm{~m}$ )下 
部为蓝灰色、灰绿色、灰白色膏泥岩与石膏层互层, 中部为紫红色钻质泥岩、粉砂岩夹砂岩, 上部为灰红 色泥岩与灰绿色含砾粗砂, 粗砂岩互层, 夹少量砾岩 层. 临夏组 $(\mathrm{N} l$, 厚 $279.8 \mathrm{~m})$ 自下而上划分为柳树段 $\left(\mathrm{N}_{1} l\right)$ 和何王家段 $\left(\mathrm{N}_{1-2} h\right)$. 柳树段(厚 $106.4 \mathrm{~m}$ )下部为灰 红色、灰绿色砾岩、含砾粗砂岩, 中-细砂岩与灰红色 粉砂岩、泥岩互层, 上部为灰白色、灰红色、暗灰色 粉砂岩、钙质泥岩, 局部见泥灰岩, 夹砾岩和含砾粗 砂岩. 柳树段底部产时代为中新世晚期的三趾马等 化石 ${ }^{4}$. 何王家段(厚 $173.4 \mathrm{~m}$ )下部为浅灰色中-粗砾 岩与灰黄色中-粗砂岩互层, 上部为土黄色中-细砂岩 与土红色、黄褐色钻质泥岩互层, 夹少量泥灰岩. 上 述他拉组、咸水河组和临夏组之间及内部各段均为整 合接触. 积石组 $\left(\mathrm{N}_{2} j\right.$, 厚 $\left.>290 \mathrm{~m}\right)$ 为黄灰、灰黄色、浅 灰、紫红色等杂色厚-巨厚层状复成分砾岩夹粗砂岩 和泥质粉砂岩透镜体, 为洪积扇-河流相沉积, 与下 伏何王家段不整合接触. 我们在循化县积石镇羊圈 贡拜村至西沟村的他拉组一临夏组实测剖面上获得如 下磁性地层年龄: 他拉组上部为 23.2 21.3 Ma, 咸水 河组为 21.3 9.6 Ma(中庄段为 21.3 17.1 Ma、上庄段 为 17.1 14.6 Ma、东乡段为 14.6 9.6 Ma), 临夏组为 9.6 5 Ma (柳树段 9.6 7.3 Ma、何王家段为 7.3 5 Ma). 循化-化隆盆地是在白严纪古盆地的基础上, 于 约 $29 \mathrm{Ma}$ 开始再次抝陷. 盆地南部边缘为西秦岭北缘 逆冲带, 北部边缘为拉脊山逆冲带. 拉脊山逆冲带在 该时期双向逆冲隆升，致使与拉脊山逆冲带北侧的 西宁盆地分割 ${ }^{[49]}$, 其盆地沉积物源主体来自于逆冲 带. 盆缘新生代红层与基底地层在盆地边缘多为断 层接触, 局部为角度不整合接触. 向盆缘产状逐渐变 陡, 向盆地内部产状逐渐变缓至水平岩层. 年龄大于 23.2 Ma的他拉组砾岩为盆地初始压陷期的沉积, 西 秦岭北缘逆冲带控制了该盆地他拉组粗碎屑冲积扇 沉积. 21.3 9.6 Ma(咸水河组) 以富含膏盐层的咸化湖 相细碎屑沉积为主, 指示盆地进入湖盆扩张最大期 与稳定期. 9.6 5 Ma(临夏组)湖盆沉积区开始萎缩, 进入湖缘的水下扇砾岩和砂岩层增多, 明显表现出 水体向上变浅的进积型序列. 约 $4 \mathrm{Ma}$ 左右由于周缘 山系强烈逆冲与盆地整体隆升, 导致了积石组与下 伏临夏组之间的沉积间断与不整面的发育. 约 3.6
$\mathrm{Ma}$ 以后盆地内广泛分布的上新世积石组巨砾岩是该 时期周缘山系进一步隆升的沉积响应.

\section{3 芫塘-川西地层区沉积特征与演变}

芫塘-川西地层区根据盆地类型和盆地沉积充填 序列特征，划分为羌塘地层分区，可可西里-玉树地 层分区和川西-藏东地层分区(图 1,2).

\section{1 㒸塘地层分区}

包含 16 个盆地, 分别为阿克苏库勒、云母山、 黑石北湖-羊湖、拜惹布错-黄土岗达坂、雅西尔沟拉竹龙、龙木错、阿鲁错-四家湖、万泉湖、吐错、 丁固、改则、伦坡拉、其香错、安多、巴青和那曲盆 地(图 1). 阿克苏库勒和云母山盆地盆地均为走滑拉 分盆地, 盆地主要接受沉积是在古近纪, 以河流-湖 泊沉积为主. 黑石北湖-羊湖、万泉湖、吐错和丁固盆 地是受东西向大断裂影响形成的压陷盆地，这些盆 地是明显地呈东西向分布的大-中型盆地, 沉积物皆 以粗碎屑岩韵律堆积为特征, 沉积厚度较大. 龙木错 盆地和万泉湖盆地均为抝陷盆地, 盆地内连续沉积 了古近纪-新近纪的地层, 以河流-湖泊沉积为主, 早 期以粗碎屑的冲洪积扇和河流沉积为特征，中-晚期 主要以湖泊沉积为主 ${ }^{[50]}$. 伦坡拉盆地是主压应力方 向为近南北向, 湖泊走向(湖泊长轴方向)近东西向, 是在燕山构造阶段褶皱基底上发育起来的古近纪拗 陷盆地 ${ }^{[51]}$. 伦坡拉盆地古近纪早期以粗砾碎屑沉积 为主, 晚期以细粒沉积为主, 主要为河流-湖泊沉 积 ${ }^{[52,53]}$, 古近纪与新近纪地层以角度不整合面为界. 该分区的岩石地层可区分为沉积岩地层和火山岩地 层两套序列(图 2).

该分区的沉积岩地层单位是牛堡组、丁青湖组、 康托组、吵呐湖组和布隆组(图 2). 牛堡组 $\left(\mathrm{E}_{1-2} n\right.$, 厚 $551 \mathrm{~m}$ )底部为棕红色砾岩, 中上部为灰色、灰绿色泥 岩夹泥灰岩、油页岩和凝灰岩，自下而上含 4 个介形 虫组合: Limnocythere-Eucyprisy组合、LimnocythereCypris-Cyprinotus组合、Limnocythere-CyprisEucypris-Candona 组合和Cypinotus-Candona组合 ${ }^{[54]}$. $\mathrm{E}_{1-2} n$ 古地磁年代为 57 47 $\mathrm{Ma}^{[20]}$. 丁青湖组 $\left(\mathrm{E}_{3} d\right.$, 厚 $564.5 \mathrm{~m})$ 为湖相紫红、灰绿色泥岩、凝灰岩夹油页岩、

4) 中国地质大学(武汉)地质调查研究院. 青海 $1: 5$ 万奴合家幅、校都乡幅区域地质调查报告. 2008 
泥灰岩, 自下而上含 2 个介形虫组合: AustrocypisCyprinotus-Pelocypris 组合和Ilyocypris-Limnocythere 组合 ${ }^{[11]}$, 其时代为渐新世. 康托组(EN $k$, 厚 $1199.5 \mathrm{~m}$ ) 为紫红色砾岩夹紫红、浅灰、灰黑色砂岩、含砾砂岩、 粉砂岩、粉砂质泥岩等, 局部夹中基性熔岩和碳酸盐 岩. EN $k$ 含渐新世-中新世早期狍粉Engelhardtiodites, Multicellaesporites, Taxodiaceaepollenites, Piceaepollenites, Onychium, Pinus, Betula, Plerocarya, Alnus, Corylus, Ouercus, Fagus, Ulmus, Monoletes 等 ${ }^{5)}$. ENk 下部火山岩夹层 $\mathrm{K}-\mathrm{Ar}$ 年龄为 $29.6 \mathrm{Ma}^{6}$. 综合孢粉和 火山岩年龄, 本文推测 $\mathrm{EN} k$ 沉积应始于始新世, 结束 于中新世中期. 唢呐湖组 $(\mathrm{N} s$, 厚 340 1740 m) 为紫 红、砖红色砂岩、粉砂岩和泥质岩夹砾岩、含砾砂岩 和多层石膏及膏泥岩, 向盆地边缘相变为灰紫-灰红 褐色砾岩夹紫红色含砾粗砂岩, 向盆地内部部分地 区相变为淡水灰岩. N s 产腹足类Planorbies, P. youngi, Lymnaea sp., Gyraulus sp.; 双壳类Sphaerium sp., S. aff. nitidum 等 ${ }^{[5]}$, 据化石组合其时为中新世-上新世. 布隆组 $\left(\mathrm{N}_{2} b\right.$, 厚 $\left.>28.7 \mathrm{~m}\right)$ 下部为灰、黄灰及褐灰色泥 岩, 中部为松散胶结的石英砂与薄层泥岩互层, 上部 为灰褐色泥岩. 比如县下秋卡区布隆乡一带的 $\mathrm{N}_{2} b$ 产 哺乳动物三趾马、犀牛等及植物化石云杉、山核桃、 罗汉松、雪松等 ${ }^{7)}$, 据化石组合将其置于上新世.

火山岩地层为美苏组、纳丁错组、鱼鳞山组和石 坪顶组(图 2). 美苏组 $\left(\mathrm{E}_{2} m\right.$, 厚 $>1564 \mathrm{~m}$ ) 为一套基性酸性火山熔岩为主夹火山碎屑岩组合, 主要岩性为 英安质(流纹质)晶屑岩屑凝灰岩、火山角砾岩、英安 岩、流纹岩、安山岩、玄武安山岩、玄武岩夹凝灰质 砂岩. 在 $\mathrm{E}_{2} m$ 中获得 $(69.07 \pm 2.1) \mathrm{Ma}$ (安山岩)、 $(63.63 \pm 0.97) \mathrm{Ma}$ (流纹岩)、(59.90 \pm 1.93$) \mathrm{Ma}$ (安山岩)、 (39.37 \pm 2.7$) \mathrm{Ma}$ (安山岩)、(36.96 \pm 0.86$) \mathrm{Ma}$ (英安岩)和 (35.27 \pm 0.51$) \mathrm{Ma}$ (英安岩) 6 个K-Ar法同位素年龄 值 ${ }^{8), 9)}$, 故美苏组时代为古新世-始新世. 纳丁错组 $\left(\mathrm{E}_{3} n\right.$, 厚 $\left.291 \mathrm{~m}\right)$ 为杂色安山质火山角砾岩、含火山角 砾安山质晶屑凝灰岩、橄榄玄武岩、玄武岩和安山岩,
$\mathrm{K}-\mathrm{Ar}$ 同位素年龄值为 $32.60 \mathrm{Ma}^{[56]}$, 为渐新世. 鱼鳞 山组(ENy, 厚 525 1069 m)下部主要由暗褐色安山 岩、安山质火山角砾岩、霓辉石粗面岩、粗面岩和浅 灰、灰白色英安质熔岩组成的钙碱系列的中酸性火山 岩系, 上部主要由灰、深灰色碱性玄武岩、白榴碱玄 岩、灰褐、灰绿色白榴碧玄岩、云辉煌岩、白榴石响 岩、䵢方石响岩、霞石响岩、蓝方石响岩、霓辉粗面 岩、斑状粗面岩、橄辉白榴斑岩和云母霞石正长岩等 组成的一套碱性、过碱性中基性火山岩和次火山岩. 在ENy中获得 32.2 和 $28.2 \mathrm{Ma}$ 的Ar-Ar法年龄值 ${ }^{[57]}$, $19.1 \mathrm{Ma}$ 的K-Ar法年龄值 ${ }^{10)}$, 指示鱼鳞山组时代为渐 新世-中新世. 石坪顶组 (Nsp., 厚 40 200 m) 为灰黑、 灰绿、紫红色碱性粗面安山岩、辉石安山岩、安山玄 武岩、安山岩、英安岩和流纹质晶屑凝灰岩, 获得 $\mathrm{K}-\mathrm{Ar}$ 年龄值为 $16.3,12.7,9.68,9.12,6.2$ 和 $4.82 \mathrm{Ma}^{[55]}$, 指示 $\mathrm{N} s p$ 时代为中新世-上新世早期.

\section{2 可可西里-玉树地层分区}

包含 17 个盆地, 分别为可可西里-沱沱河、伯拉克 拉克里、东大滩、柯尔咱程、冬给措纳湖、麻多、曲 麻莱、跃加玛可、上拉秀、囊谦、吉曲、东坝、贡觉、 恩达、八宿、维古-色木雄和芒康盆地(图 1). 该分区 的岩石地层包含沉积岩和火山岩两套地层序列(图 2).

该分区发育的沉积岩地层主要为沱沱河组、雅西 措组、五道梁组、曲果组和昆仑组. 沱沱河组 $\left(\mathrm{E}_{1-2} t\right.$, 厚 $606 \mathrm{~m}$ )为紫红、砖红色砾岩、灰质岩屑砂岩、粉砂 质泥岩及生物碎屑灰岩组成的韵律层, 为河流-三角 洲-湖相沉积, 含孢粉、轮藻、介形虫. $\mathrm{E}_{1-2} 2$ 介形虫有 Cypris decaryi, Gautheir, Candoniella albicans, Darwinula sp.等; 轮藻有Peckichara serialis 等 ${ }^{11)}$, 古 地磁年龄为 $52.0 \sim 31.5 \mathrm{Ma}^{[23,33]}$, 为始新世-渐新世早 期. 雅西措组 $\left(\mathrm{E}_{3} y\right.$, 厚 $\left.984 \mathrm{~m}\right)$ 为紫红、灰紫色灰质中 细粒砂岩与浅灰绿色泥晶砂屑灰岩, 为三角洲-湖相 沉积, 含狍粉、轮藻和介形虫. $\mathrm{E}_{3} y$ 介形虫有Eucypris lenghuensis, Darwinula sp., Candoniella albicaus,

\footnotetext{
5) 四川省地质调查院. 西藏 1:25 万物玛幅区域地质调查报告. 2006

6) 西藏自治区地质调查院. 西藏 1:25 万改则县幅区域地质调查报告. 2006

7) 西藏自治区地质调查院. 西藏 1:25 万那曲县幅区域地质调查报告. 2005

8) 江西省地质调查院. 西藏 1:25 万邦多区幅、措麦区幅区域地质调查报告. 2002

9) 江西省地质调查院. 西藏 1:25 万喀纳幅、日土县幅区域地质调查报告. 2005

10) 贵州省地质调查院. 西藏 1:25 万加错幅、丁固幅区域地质调查报告. 2005

11) 青海省地质调查院. 青海 1:25 万沦沱河幅、曲柔尔卡幅区域地质调查报告. 2005
} 
Cyprinotus sp.等 ${ }^{11)}$, 古地磁年龄为 $31.5 \sim 30 \mathrm{Ma}^{[23,33]}$, 为渐新世. 五道梁组 $\left(\mathrm{N}_{1} w\right.$, 厚 $\left.399.4 \mathrm{~m}\right)$ 为浅灰绿色泥 灰岩夹石膏层、紫红色细砂岩与浅灰色泥岩, 为咸化 湖相沉积, 含孢粉和介形虫. $\mathrm{N}_{1} w$ 介形虫为 Eucypris goibeigouensis, E. qaibeigouensis, Limnocythere limbosa, Candoniella marcida, Mandelstam, Cyclocypris sp., Darwinula nadinae 等 ${ }^{11)}$, 为中新世, 古地磁 年龄为 $23.8 \sim 21.8 \mathrm{Ma}^{[33]}$. 曲果组 $\left(\mathrm{N}_{2} q\right.$, 厚 1070 2283 m)下部为灰褐色砾岩、粉砂岩及薄层状泥岩夹岩屑砂 岩; 上部为灰、灰褐色薄层状泥粒灰岩、泥岩夹粉砂 岩, 为扇三角洲-湖泊相沉积, 产轮藻Charites sp., 腹 足类Galba sp., 介形虫Candona sp., Candoniella sp., Cyclocypris sp., Ilyocypris sp., Eucypris sp., Leucocythere aff. tropis, Candoniella formosa 等 ${ }^{12)}$, 据化石归 为上新世. 昆仑组 $\left(\mathrm{N}_{2} k l\right.$, 厚 $\left.250 \mathrm{~m}\right)$ 为洪积相杂色砂质 砾岩, 古地磁年龄为 3.58 2.69 $\mathrm{Ma}^{[58]}$. 分布在该分区 东部的一些小型拉分盆地内(如贡觉、芒康等盆地)所 发育的新生代沉积地层单位还有贡觉组、宗白组和拉 屋拉组等, 将在本文 3.3 节中叙述. 火山岩地层为查 保马组和湖东梁组. 查保马组 $\left(\mathrm{N}_{1} c\right.$, 厚 $\left.>2000 \mathrm{~m}\right)$ 为紫 灰、灰黄色玄武安山岩、粗面安山岩、粗面岩、粗面 英安岩夹次火山岩、深灰色玄武安山玢岩、粗面斑岩. 在 $\mathrm{N}_{1} c$ 中获得 $18.28 \mathrm{Ma}$ 的SHRIMP法锆石 U-Pb年龄 ${ }^{(13)}$. 湖东梁组 $(\mathrm{NQ} h)$ 为浅灰、肉红、灰紫红色流纹岩、流 纹质角砾熔岩、霏细岩、次粗面英安岩及次流纹岩, 获得 $(24.0 \pm 0.19) \mathrm{Ma}$ (熔岩)、(6.63 \pm 0.07$) \mathrm{Ma}$ (次火山岩) 的Ar-Ar法年龄和 $2.2 \mathrm{Ma}$ (次火山岩)的U-Pb法年龄 ${ }^{[59]}$.

可可西里-沱沱河盆地为受近东西向断裂影响的 断拗盆地, 位于巴颜喀拉地块西段和芫塘地块的北 部, 覆盖金沙江缝合带. 北部以昆仑南缘缝合带为界, 南部以唐古拉断层为界. 盆地内的新生代沉积(沱沱 河组)与下伏的石炭系-三叠系角度不整合接触. 可可 西里-沱沱河盆地在新生代经历了 7 个演化阶段 ${ }^{[23]}$, 这 7 个阶段分别是沱沱河组(刘志飞等 ${ }^{[23]}$ 称之为风火 山群)发育的 4 个阶段(约 56 52, 52 43, 43 38.2, 38.2 31.5 Ma); 雅西措组发育的 2 个阶段(31.5 31, 31 30 Ma); 五道梁组发育的 1 个阶段(约 23 16 Ma). 可可西里盆地发育的前 6 个阶段(56 30 Ma)均以湖泊
沉积为主, 沉积中心逐渐向北、向东迁移, 盆地南缘和 西缘的构造逆冲作用逐步加强. 在晚渐新世(30 23 $\mathrm{Ma})$ 盆地经历了抬升变形, 没有沉积作用发生 $\left(\mathrm{E}_{3} y\right.$ 与 $\mathrm{N}_{1} w$ 之间的角度不整合和沉积缺失), 而且在晚渐新 世发生强烈南北向地壳缩短, 反映青藏高原腹地早 期隆升过程是依靠地壳南北向缩短和东北向逆冲扩 展作用来实现的 ${ }^{[23]}$.

囊谦盆地为一走向近北北西的狭长盆地. 该盆 地是在金沙江断裂带和澜沧江断裂带及其平行的次 级断裂带, 在高原腹地为逆冲挤压环境下, 沿金沙江 断裂带与其分支帚状断裂带之间出现的走滑拉分盆

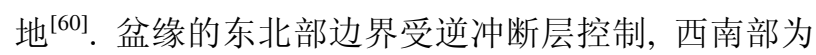
侵蚀边界. 盆内古近系与其下伏的石炭系和三叠系 的碳酸盐岩基底呈角度不整合关系. 盆地内沉积物 分布具如下规律: 由东到西, 沉积粒度变小, 沉积体 系由冲积扇迅速变为三角洲, 向西过渡为面积广泛 的湖泊体系, 表现为在盆地内沉积物分布的不对称 性. 盆地东侧靠近扎曲断裂为巨厚的砾岩, 中部过渡 为砂岩与泥灰岩韵律互层. 古流向研究揭示物源的 单一性及盆地不断加大的特征 ${ }^{[61]}$. 与囊谦盆地相邻 的同类型的拉分盆地还有曲麻莱盆地、跃加玛可盆地 和上拉秀盆地(图 1).

吉曲、东坝、恩达、贡觉、八宿、维古-色木雄 和芒康 7 个盆地均是在澜沧江断裂带和班公湖-怒江 断裂带及其平行的次级断裂带, 在逆冲挤压环境下, 沿上述断裂带与其分支帚状次级断裂带之间出现走 滑拉分盆地(图 1). 盆地内新生代沉积以河流-湖泊相 沉积为主, 粗碎屑岩厚度大且分布广泛, 与下伏地层 呈角度不整合接触. 这些新生代拉分盆地,盆缘受逆 冲-走滑断裂控制, 盆内地层已广泛褶皱, 岩浆活动强 烈 ${ }^{[2,60,62,63]}$. 对贡觉盆地的新生代沉积地层中的高钾 钻碱性中、酸性火山岩的研究表明, 7 个火山岩样品 的K-Ar全岩和黑云母的表面年龄为 40.8 46.2 Ma (平 均值 $44.2 \mathrm{Ma})^{[62,63]}$, 火山活动发生在印度-欧亚板块 碰撞后形成的构造环境中, 受陆内水平剪切-走滑断 裂带控制 ${ }^{[62,63]}$. 芒康盆地内拉屋拉组高钾火山岩的 ${ }^{40} \mathrm{Ar}{ }^{39} \mathrm{Ar}$ 年龄为 $(33.5 \pm 0.2) \mathrm{Ma}^{[64]}$, 同位素地球化学示 踪结果表明, 高钾火山岩是在陆内俯冲背景下产生 的 ${ }^{[64]}$.

12) 中国地质大学(武汉)地质调查研究院, 青海省地质调查院. 青海 1:25 万阿拉克湖幅区域地质调查报告. 2003

13) 中国地质大学(武汉)地质调查研究院. 青海 1:25 万库塞湖幅、不冻泉幅区域地质调查报告. 2006 


\section{3 川西-藏东地层分区}

包含 8 个盆地, 分别为玛曲、甘德、桑日麻、长 沙贡玛、甘孜、羊拉、硕曲和拉波盆地. 它们均是在 金沙江断裂带、澜沧江断裂带和班公湖-怒江断裂带 及其平行的次级断裂带, 在逆冲挤压环境下, 沿上述 断裂带与其分支帚状次级断裂带之间出现小型走滑 拉分盆地(图 1). 这些小型盆地的共同特点是: (1) 平 面上沿断裂带呈狭窄的长条状, 分布面积小; (2) 盆 地内的沉积建造多数以快速堆积的冲积扇-河流相砾 岩、砂岩开始, 中期进入湖相泥岩、泥灰岩、粉砂岩 夹灰岩、泥质石膏层等, 晚期又以河流-冲积扇相砂砾 岩结束, 盆地沉积充填期相对短暂; (3) 盆地沉积建 造巨厚，一般厚度在千米以上; (4) 部分盆地常伴有 火山岩分布 ${ }^{[34,35]}$. 该分区发育的岩石地层为热鲁组、 贡觉组、宗白组、昌台组和拉屋拉组. 热鲁组 $\left(\mathrm{K}_{2} \mathrm{E} r\right.$, 厚数百米至 $2000 \mathrm{~m}$ ) 下部为紫红、红色砾岩、含砾粗 砂岩, 上部为杂色含砾砂岩、砂岩、砾岩与泥岩互层 夹泥灰岩、白云质灰岩, 局部夹火山碎屑岩, 局部地 段的泥岩含铜, 为冲积扇-扇三角洲-湖泊相沉积, 产 古近纪植物Palibinia pinnatifida, Eucalyptus relunensis, Bansia puryearemsis, Hemiptelea paradavidii及 轮藻Gyrogona gianjiangica 和Kosmogyra sp. 等 ${ }^{14)}$. 在 德格 $\mathrm{K}_{2} \mathrm{E} r$ 中发现大量以晚白严世为主的孢粉如 Ginkgocycadophytus, Psophosphaera 等 ${ }^{15)}$, 在你岔马 $\mathrm{K}_{2} \mathrm{E} r$ 中也获得晚白严世孢粉化石 ${ }^{[65]}$, 故将热鲁组时 代定为晚白严世-古近纪. 贡觉组 $\left(\mathrm{E}_{1-2} g\right.$, 厚 1200 2646 $m$ )下部为紫红色砾岩与含砾砂岩、砂岩和钻泥质粉砂 岩互层夹石膏, 上部为红色砂岩、泥岩、泥质粉砂岩 夹泥灰岩、石膏层及含铜页岩, 产古近纪植物 Sabalites 和Pinus yunnanensis ${ }^{[11] 16)}$. 宗白组 $\left(\mathrm{E}_{2} z\right.$, 厚 $294 \mathrm{~m})$ 下部为灰、灰黄、灰褐色厚层细砾岩、砂岩, 上 部为灰色粘土岩、泥岩、黑色页岩夹灰黄色中细粒砂 岩、粉砂岩及油页岩. $\mathrm{E}_{2} z$ 在热昌产腹足类 Planorbarius subdiscus, Pingiella dengqenensis, Guraulus sp., 在八达产植物Equiselum sp. ${ }^{17)}$, 在宗白 产腹足类Viviparus sp., Lymnaea sp., Pingiella dengqenensis, Gyraulus sp., Planorbarius sp., Amnicola sp., Pseudamnicola sp., Physa sp.; 介形虫Stenocypris sp., Cyprois sp., Eucypris sp.; 昆虫 Erotylidae

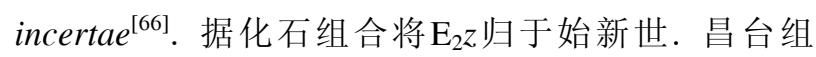
$(\mathrm{N} c$, 厚 $1329 \mathrm{~m})$ 在昌台地区为紫红、红、灰色砾岩、 含砾砂岩、砂岩、粉砂岩、泥岩夹含油褐煤及菱铁 矿结核,下部夹中基性火山岩, 在玉隆 $\mathrm{N} c$ 为灰绿色粉 砂岩、粉砂质泥岩与砂岩互层夹透镜状砾岩, 夹少 量中基性火山碎屑岩. $\mathrm{N} c$ 含腹足类Planorbis youngi, Planorbis cf. Chihliensis; 孢粉 Pinuspollnites sp., Podocarpidites $\mathrm{sp}^{15)}$, 据化石组合为中新世. 拉屋拉 组 $(\mathrm{EN} l$, 厚 $1024 \mathrm{~m})$ 为紫红、灰白、黄绿色砂岩、砾 岩、泥岩、粉砂岩, 局部含凝灰岩及薄煤层, 中部为 中酸性碱性粗面岩、粗安岩、石英粗安岩、黑云母石 英粗面岩等夹杂色砂砾岩, 产孢粉Equisetum sp., Betula mankongensis, B. cf. utilis, B. cf. vera, Carpinus cf. fargesiana, C. Grandis, Sorbus cf. wilsoniana, Lonicera sp., Chenopodium sp., Polygonum sp., Artemisia sp.等; 介形虫Stenocypia fischeri, Candoniella donschanensis; 腹足类Australorbis cf. pseuduammonius; 轮藻Obtusochara $\mathrm{sp} .^{[11]}$. 中部火山岩的 ${ }^{40} \mathrm{Ar} /{ }^{39} \mathrm{Ar}$ 年龄为 $(33.5 \pm 0.2) \mathrm{Ma}^{[64]}$, 综合测年值和化石 组合, 本文将EN $l$ 时代置于渐新世-上新世.

\section{4 扬子西缘地层区沉积特征与演变}

根据盆地类型和盆地沉积充填序列将扬子西缘 地层区划分为成都地层分区和滇西地层分区(图 1).

\section{1 成都地层分区}

成都地层分区仅含成都盆地，为挤压构造背景 下的构造挠曲压陷盆地. 新生代沉积地层为一套大 型河湖相碎屑岩沉积组合，从老至新岩石地层序列 为大溪组 $\left(\mathrm{K}_{2} \mathrm{E}_{1} d\right)$ 、名山组 $\left(\mathrm{E}_{1-2} m\right)$ 、柳嘉组 $\left(\mathrm{E}_{1-2} l j\right)$ 、芦 山组 $\left(\mathrm{E}_{2-3} l\right)$ 、凉水井组 $(\mathrm{N} l s)$ 和大邑组 $\left(\mathrm{N}_{2} \mathrm{Qp} d\right)$, 与下伏 白严纪陆相地层为连续沉积 ${ }^{[15,34,35]}$. 盆地内新生界岩 石地层序列在渐新统与中新统、中新统与上新统之间

14）四川省地质调查院. 四川 1:25 万阿坝县幅区域地质调查报告. 2006

15）四川省地质调查院. 四川 1:25 万甘孜县幅区域地质调查报告. 2001

16) 西藏自治区地质调查院. 西藏 $1: 25$ 万贡觉县幅区域地质调查报告. 2007

17) 西藏自治区地质调查院. 西藏 $1: 25$ 万丁青县幅区域地质调查报告. 2006 
均存在沉积间断与角度不整合面 ${ }^{[15,34,35]}$. 该分区各岩 石地层单位的沉积特征与时代归属见图 2.

\section{2 滇西地层分区}

滇西地层分区包含 13 个盆地(图 1), 按盆地性质 和沉积特征可分为 5 种类型. 类型 1 包括西昌、盐边、 盐源、宁莨和丽江盆地(图 1), 均为拉分盆地. 类型 1 盆地新生代沉积地层为山麓洪冲积-河湖相碎屑岩沉 积组合, 从老至新岩石地层序列为丽江组、盐源组或 昔格达组 ${ }^{[10,34,35]}$ (图 2). 类型 2 包括昭通、昆明、几依、 元谋和楚雄 5 个断陷盆地(图 1). 类型 2 盆地新生代 沉积为一套河湖相碎屑岩组合, 与下伏白严纪陆相 地层连续沉积, 在渐新统与中新统、中新统与上新统 之间均存在沉积间断与角度不整合面, 岩石地层序 列为小坝组 $(\mathrm{KE} x)$ 、雷打树组 $(\mathrm{E} l)$ 、江底河组 $(\mathrm{KE} j)$ 、 赵家店组 $\left(\mathrm{E}_{2} z \mathrm{j}\right)$ 、路南组 $\left(\mathrm{E}_{2-3} l n\right)$ 、小龙潭组 $\left(\mathrm{N}_{1} x l\right)$ 、高

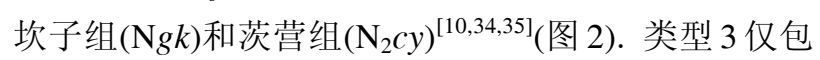
含剑川 1 个盆地, 是在澜沧江断裂带和红河断裂带及 其平行的次级断裂带内, 在逆冲挤压环境下, 沿上述 断裂带出现的走滑拉分盆地(图 1). 剑川盆地新生代 地层为一套山麓相-河湖相碎屑岩-火山喷发、溢流相 沉积组合, 盆地内岩石地层序列在渐新统与中新统、 中新统与上新统之间均存在沉积间断与角度不整合 面, 从老至新岩石地层序列是宝相寺组 $\left(\mathrm{E}_{2} b\right)$ 、金丝厂 组 $\left(\mathrm{E}_{3} j\right)$ 、双河组 $\left(\mathrm{N}_{1} s h\right)$ 和剑川组 $(\mathrm{N} j)^{[10,34,35]}$ (图 2). 类型 4 仅包含兰坪 1 个盆地, 是在澜沧江断裂带和红河断 裂带及其平行的次级断裂带内, 在逆冲挤压环境下, 沿上述断裂带出现的走滑拉分盆地(图 1). 兰坪盆地 新生代地层为一套山麓相-河湖相碎屑岩沉积组合, 发育湖沼相的煤层, 与下伏白严纪陆相地层为连续 沉积, 盆地内岩石地层序列在始新统内部、渐新统与 中新统、中新统与上新统之间均存在沉积间断与角度 不整合面, 从老至新岩石地层序列为预野井组 $\left(\mathrm{E}_{1} m\right)$ 、 等黑组 $\left(\mathrm{E}_{2} d\right)$ 、宝相寺组 $\left(\mathrm{E}_{2} b\right)$ 、预腊组 $\left(\mathrm{E}_{2-3} \mathrm{ml}\right)$ 、三号 洞组 $\left(\mathrm{N}_{1} s\right)$ 和三营组 $\left(\mathrm{N}_{2} s y\right)^{[10,34,35]}$ (图 2). 类型 5 包含腾 冲 1 个盆地, 是班公湖-怒江断裂带平行的次级断裂 带内在逆冲挤压与走滑构造环境下, 出现的山间断 陷盆地 (图 1). 滕冲盆地内仅发育上新统芒棒组 $\left(\mathrm{N}_{2} m\right)^{[10,34,35]}$ (图 2). 该分区各岩石地层单位的沉积特 征与时代归属见图 2.

\section{5 冈底斯-喜马拉雅-恒河地层区沉积特征与 演变}

冈底斯-喜马拉雅-恒河地层区根据盆地类型和 盆地沉积充填序列特征, 划分为冈底斯地层分区、雅 江-喜马拉雅地层分区和恒河地层分区(图 1,2).

\section{1 冈底斯地层分区}

包含冈底斯陆缘岩浆弧和分布在该岩浆弧两侧 及叠置之上的 8 个盆地(图 1). 盆地按其形成机制可 分为藏南残留海、拉分盆地和断陷盆地三种类型. 藏 南残留海是指古新世-始新世分布在冈底斯陆缘岩浆 弧南侧的新特提斯残留海. 从渐新世开始至新近纪, 沿该带出现了新的拉分盆地和断陷盆地. 拉分盆地 包括克勒策、巴噶和桑桑盆地. 断陷盆地分布在冈底 斯陆缘岩浆弧的北侧, 有雄巴、昂拉仁错、措勤-扎日 南木错、郭拉-乌郁和曾错盆地. 该分区的岩石地层可 区分为沉积岩地层和火山岩地层两套序列(图 2).

古新世-始新世期间，陆缘弧内发育了大量䥻碱 性-高钾䥻碱性火山岩系(林子宗群)。陆缘弧在火山 活动间隙期的火山凹地内堆积了陆相河湖环境沉积 (林子宗群内的大套沉积岩夹层). 在陆缘弧南侧的盆 地内, 发育了以柳曲群和错江顶群为代表的海陆过 渡-滨浅海环境沉积. 在陆缘弧北侧的一系列断陷盆 地内, 发育了以牛堡组和秋乌组为代表的河湖陆相 环境沉积. 无论是南侧的古近纪浅海相地层, 还是冈 底斯陆缘岩浆弧内发育的古近纪火山岩, 它们均与 下伏的白严纪海相地层之间呈角度不整合接触关系, 说明印度与欧亚板块沿雅鲁藏布江带的初始碰撞发 生在古新世初(65 Ma). 始新世晚期, 冈底斯陆缘岩 浆弧南侧的新特提斯残留海全面向西退去, 从而全 面结束了该带的海相沉积地层 ${ }^{[34,35]}$. 该带并连同冈 底斯陆缘弧的大部分地区被构造抬升为剥蚀区，说 明印度与欧亚板块沿雅鲁藏布江带完成了全面碰撞, 进入陆内演化阶段. 至渐新世, 沿冈底斯南缘出现了 一些呈近东西向展布的狭条状构造走滑拉分盆地, 盆地内堆积了以粗碎屑为主的洪冲积-河湖相-水下扇 沉积(大竹卡组和日贡拉组). 至新近纪, 冈底斯南、 北侧的拉分和断陷盆地内均充填了洪冲积-河流-扇三 角洲-湖泊环境沉积(芒乡组、乌郁群、旦增竹康组、 沃马组和布隆组), 局部发育陆相火山岩(鱼鳞山组和 布嘎寺组). 该分区火山岩地层十分发育, 主要有林 
子宗群、鱼鳞山组和布嘎寺组 (图 2), 另外在以沉积 岩为主的地层中如日贡拉组、芒乡组和乌郁群中均含 有火山岩夹层. 林子宗群( $E L)$ 从下向上分为典中组、 年波组和帕那组. 典中组 $\left(\mathrm{E}_{1} d\right.$, 厚 1162 5160 m) 以中 性、中-酸性火山岩及火山碎屑为主的岛弧型火山岩 组合, 主要岩性为灰绿色安山质、英安质、流纹质熔 岩和火山碎屑岩, 夹少量沉积岩层, 时见底砾岩. $\mathrm{E}_{1} d$ 火山岩Ar-Ar法年龄为 64.4 60.5 $\mathrm{Ma}^{[67]}$, 锆石 $\mathrm{U}-\mathrm{Pb}$ 年 龄为 62.5 和 $64.8 \mathrm{Ma}^{[68,69]}$, 属古新世. 年波组 $\left(\mathrm{E}_{2} n\right.$, 厚 $721 \mathrm{~m}$ ) 为一套中-酸性火山碎屑岩和沉积碎屑岩组合, 火山碎屑岩为安山质晶屑岩屑凝灰岩, 安山-流纹质 火山角砾岩, 局部见少量英安质玻屑凝灰熔岩; 沉积 岩主要为复成分砾岩、长石岩屑砂岩、粉砂岩等. $\mathrm{E}_{2} n$ 火山岩锆石 $\mathrm{U}-\mathrm{Pb}$ 年龄为 59.7 和 $56.4 \mathrm{Ma}^{[68,69]}, \mathrm{Ar}-\mathrm{Ar}$ 法年龄为 $54.1 \mathrm{Ma}^{[70]}$, 属始新世. 帕那组 $\left(\mathrm{E}_{2} p\right.$, 厚 $2247 \mathrm{~m}$ ) 为中酸性火山碎屑岩夹熔岩, 主要有流纹质 (英安质) 晶屑凝灰岩、火山角砾晶屑凝灰岩、流纹岩 和英安岩. $\mathrm{E}_{2} p$ 火山岩Ar-Ar法年龄为 48.7 43.9 $\mathrm{Ma}^{[67]}$, 锆石U-Pb年龄为 $48.7 \mathrm{Ma}^{[69]}, \mathrm{K}-\mathrm{Ar}$ 法年齡有 $(44.4 \pm 0.8)$, $39.5 \mathrm{Ma}$ 值 ${ }^{18)}$, 为始新世中期. 本文将四川省地质调 查院 ${ }^{19}$ 在革吉县邦巴所建的邦巴组归入帕那组. 鱼 鳞山组 $(\mathrm{EN} y$, 厚 $884 \mathrm{~m}$ ) 为灰色、灰绿色白榴石碱玄质 响岩、粗面岩、玄粗岩、碱玄岩, 安粗岩、安山岩和 少量英安质晶屑凝灰岩、粗面质角砾岩, 底部为含细 砾长石石英砂岩、沉凝灰岩. ENy火山岩 $\mathrm{K}-\mathrm{Ar}$ 法年龄 值 有 $(21.48 \pm 0.36),(19.43 \pm 0.31),(14.96 \pm 0.25)$, $(11.94 \pm 1.19) \mathrm{Ma}^{20)}$ 和 $20.1,(19.04 \pm 0.97), \quad 12.6$, $(14.22 \pm 0.68) \mathrm{Ma}^{8)}$, 李才等 ${ }^{[71]}$ 对建组剖面(改则县北西 $188 \mathrm{~km}$ 的鱼鳞山)中的白榴石响岩测得Ar-Ar法年龄 值 $27.8 \mathrm{Ma}, \mathrm{K}-\mathrm{Ar}$ 法年龄值 30 18 Ma, 综上所述, ENy 时代为渐新世晚期-中新世. 四川省地质调查院 ${ }^{19}$ 在 革吉县雄巴命名的雄巴组为一套陆相䥻碱性中、酸性 火山岩及火山碎屑岩系列, 时代为中新世, 本文将其 归入鱼鳞山组. 布嘎寺组 $\left(\mathrm{N}_{1} b\right.$, 厚 $\left.331 \mathrm{~m}\right)$ 主要为灰 色、紫灰、灰绿色黑云霓辉粗面岩、玻基黑云霓辉粗 面岩及粗面质火山集块岩、火山角砾岩和凝灰质砾岩 组成的多个火山喷发韵律, K-Ar法年龄为 15.8 ,

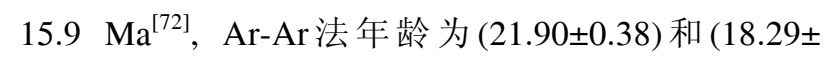
$0.30) \mathrm{Ma}^{21)}$, 时代为中新世.

该分区发育的沉积岩地层为牛堡组、秋乌组、日 贡拉组、大竹卡组、芒乡组、乌郁群和布隆组.

牛堡组 $\left(\mathrm{E}_{1-2} n\right.$, 厚 $\left.2799 \mathrm{~m}\right)$ 下部为紫红、褐黄、灰 绿色复成分砾岩、砂岩夹粉砂岩, 上部为紫红和灰绿 色砂岩、砾岩、粉砂岩和泥岩构成的韵律层, 含腹足 类Pyrazus montensis, Batillaria (Vicinocerithium) inopinata, Harrisianella (Teliostomopsis) regularicostata, Thericium (Pseudoaluco) cf. dejaeri, T. (Chondrocerithium) cf. koeneni, Bittium versigranulum 等 $^{19)}$, 时代为古近纪. 秋乌组 $\left(\mathrm{E}_{2} q\right.$, 厚 100 1827 m)下 部为灰绿色砾岩、含砾粗砂岩、中粒砂岩夹粉砂岩和 粉砂质泥岩, 中部为灰色砂岩、岩屑砂岩夹粉砂岩和 泥岩, 上部为深灰色砂岩、灰黑色泥质粉砂岩、粉砂 质泥岩夹粉砂质页岩以及薄煤多层, 为河流-扇三角 洲-湖相沉积, 含植物 Typha sp., Radicits sp., Eucalyptus oblongifolia, E. angusta, E.geinitzi, E. sp., Ficus myrtifolia, F.myrtifolia ovata, Rhamnus menshigensis, Cyperacites haydenii, Phyrnium tibeticum 等 ${ }^{20)}$, 时代为始新世. 日贡拉组 $(\mathrm{E} r$ 厚 500 1500 m) 在盆地边缘为棕红色砾岩夹紫红色含砾 砂岩、砂质泥岩和钻质泥岩, 向盆地内部相变为紫 红、灰绿色砂岩、粉砂岩、泥岩为主夹泥灰岩、含砾 砂岩和凝灰岩, 局部夹火山碎屑岩, 为河流-扇三角 洲-湖相沉积夹火山喷发堆积. $\mathrm{E} r$ 在西部仲巴-革吉一 带主要为中酸性火山岩、火山碎屑岩夹长石砂岩、粗 砂岩和泥岩, 在火山岩发育地段厚达 $4220 \mathrm{~m} . \mathrm{E} r$ 含古 近纪腹足类Bithynia sp. ${ }^{8}$, 本组下部熔结凝灰岩 $\mathrm{K}-\mathrm{Ar}$ 法年龄为 $(35.46 \pm 0.6) \mathrm{Ma}^{8)}$, 据化石和同位素年龄 $\mathrm{E} r$ 时代为渐新世. 大竹卡组 $\left(\mathrm{E}_{3} \mathrm{~N}_{1} d\right.$, 厚 $\left.150 \sim 1200 \mathrm{~m}\right)$ 以 紫红、灰色砾岩和砂岩为主, 粉砂岩、泥岩、凝灰岩 次之, 是分布在冈底斯陆缘岩浆弧南侧、雅鲁藏布缝 合带北侧的一套红色河流-冲洪积扇-扇三角洲粗碎屑 为主的沉积. $\mathrm{E}_{3} \mathrm{~N}_{1} d$ 沿朗县、加查、日喀则、昂仁、巴 噶呈由东向西带状断续分布在 $1500 \mathrm{~km}$ 以上, 在西部 噶尔门士地区该组上部的凝灰岩中产植物Artemisia sp., Albizzia sp., Poulus balsamcides, $P$

18) 湖北省地质调查院. 西藏 1:25 万拉孜县幅区域地质调查报告. 2003

19）四川省地质调查院. 西藏 1:25 万革吉县幅区域地质调查报告. 2003

20) 河北省地质调查院. 西藏 1:25 万亚热幅、普兰县幅区域地质调查报告. 2006

21) 成都理工大学地质调查院. 西藏 1:25 万赛利普幅区域地质调查报告. 2005 
cf.sinensis, P. latior, P. glandulifera, Ephedra viesenensis, Ulmus sp., Lequminosae sp等; 孢粉 Salix sp., Querus sp., Ulnus sp., Ephedra sp., E. viesenensis, Chenopodiaceae, Compositae, Quercus sp., Sophora sp.

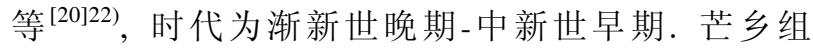
$\left(\mathrm{N}_{1} m\right.$, 厚 166 900 m) 为灰色、灰绿色含煤碎屑岩和火 山碎屑岩, 局部夹油页岩和可采煤层, 为湖泊-沼泽 相沉积, 在申扎以东曲多一带凝灰岩等火山碎屑岩 较发育，厚在 $1000 \mathrm{~m}$ 以上. $\mathrm{N}_{1} m$ 含植物化石 Betulaparautilis sp., Populus latior等 ${ }^{[20]}$. 在革吉县热 邦雄马 $\mathrm{N}_{1} m$ 的凝灰岩测得同位素年龄为 $(23.1 \pm 0.3)$ 和 $19 \mathrm{Ma}^{[20]}$, 测年数据与化石组合反映 $\mathrm{N}_{1} m$ 为中新世. 乌郁群 $(\mathrm{N} W)$ 从下向上划分为嘎扎村组和宗当村组. 嘎扎村组 $(\mathrm{N} g$, 厚 $1530 \mathrm{~m})$ 下部为紫红色含角砾晶屑 岩屑凝灰岩、灰白色砂岩夹油页岩和煤层; 中上部为 紫红色火山岩, 主要为火山集块岩、安山质熔结火山 角砾岩、安山岩和英安岩, 含植物化石Cyperacites sp., Thuja sp., Quercrs sp., Monocotyedon sp., Ulmus cf. mion pumila 和狍粉 ${ }^{23)} . \mathrm{N} g$ 火山岩年龄为 15.1 和 15.03 $\mathrm{Ma}^{[73]}$, 时代为中新世. 宗当村组 $(\mathrm{N} z$, 厚 $>500 \mathrm{~m})$ 为灰 色砾岩、砂岩、粉砂岩、泥岩韵律层夹油页岩、凝灰 质砂岩、中酸性火山岩及火山凝灰岩, 为扇三角洲湖相沉积. $\mathrm{N} z$ 下部火山岩的K-Ar法测年值为 $(9.87 \pm 0.3)$ 和 $(8.23 \pm 0.13) \mathrm{Ma}$, 上部的古地磁年龄为 $8 \sim 2.5 \mathrm{Ma}^{[74]}$, 时代为中新世-上新世. 布隆组 $\left(\mathrm{N}_{2} b\right.$, 厚 $\left.118 \mathrm{~m}\right)$ 在该 分区分布在措勤-扎日南木错盆地, 为浅紫红色砾岩 与浅紫红色含砾粗砂岩呈韵律互层夹砖红色粉砂质 泥岩, 获少量孢粉Pinus sp., Alnus sp., Granineae等及 2.9 和 $3.5 \mathrm{Ma} \mathrm{ESR}$ 年龄值 ${ }^{24)}$, 时代为上新世. 成都理 工大学地质调查院 ${ }^{24)}$ 对该套地层新建了组名, 称为 洁居纳卓组, 本文认为其岩性和时代均与布隆组相 当, 可归入布隆组.

\section{2 雅江-喜马拉雅地层分区}

分区内的新生代盆地按其形成时代与构造背景 可分为三种类型: 古近纪藏南残留海、新近纪拉分盆 地和断陷盆地.

(1) 古近纪藏南残留海: 分布在冈底斯陆缘岩浆 弧以南的广阔区域内, 由于该带自始新世未期脱离
海洋环境后一直持续隆升, 使原先的古近纪残留海 (洋)沉积物多数被剥蚀肄尽, 现残存的古近纪海相地 层仅零星分布在江孜、岗巴-定日、仲巴、萨嘎-郭雅 拉和桑麦等地(图 1). 近年野外地质调查对该分区古 近纪残留海获得了许多新发现，主要在萨嘎以西的 郭雅拉和桑麦等地(图 1), 发现有较大面积的古新世始新世的半深海-深海页岩、砂岩、含放射虫硅质岩、 玄武岩建造，如分布在雅江-喜马拉雅地层分区的古始新统蹬岗组 $\left(\mathrm{E}_{1-2} d\right)$ 、始新统盐多组 $\left(\mathrm{E}_{2} y\right)$ 和郭雅拉组 $\left(\mathrm{E}_{2} g\right.$ )(图 2); 部分地层以混杂岩形式产出, 被命名为 蹬岗混杂岩 $\left(\mathrm{E}_{1-2} d m\right)$ 、桑麦混杂岩 $\left(\mathrm{E}_{2} s m\right)$ 和盐多混杂岩 $\left(\mathrm{E}_{2} y m\right)^{22)}$ (图 2). 从当前资料分析, 雅江-喜马拉雅地 层分区古新世-始新世海相地层具有明显的沉积相带 分异. 从北向南, 海水由浅海到深海再到浅海. 北带 的浅海分布带很窄，也十分局限，见于仲巴和巴噶地 区，称错江顶群 $\left(\mathrm{E}_{1-2} C\right)$ 和柳曲群 $\left(\mathrm{E}_{1-2} L\right)$ (图 2). 南带的 浅海分布带宽，分布区域较大，见于岗巴-定日一带， 地层层序自下而上为基堵拉组 $\left(\mathrm{E}_{1} j\right)$ 、宗浦组 $\left(\mathrm{E}_{1-2} z\right)$ 和 遮普惹组 $\left(\mathrm{E}_{2} z\right)$, 以滨浅海生物碎屑灰岩为主, 富含底 栖有孔虫和钻藻 ${ }^{[9,75]}$. 在上述南北两带浅海沉积夹持 的中间地带, 为半深海-深海沉积 ${ }^{[27,76]}$. 从东向西, 半 深海-深海沉积沿江孜-萨嘎-郭雅拉-桑麦一线分布; 中带东部的江孜为半深海斜坡扇沉积建造, 称甲查 拉组 $\left(\mathrm{E}_{1} j c\right)^{[77]}$ (图 2); 中带西部为半深海-深海含放射 虫硅质岩 ${ }^{[27,76]}\left(\mathrm{E}_{1-2} d, \mathrm{E}_{2} y\right.$ 和 $\left.\mathrm{E}_{2} g\right)$ 和混杂岩建造 $\left(\mathrm{E}_{1-2} d \mathrm{~m}\right.$, $\mathrm{E}_{2} s \mathrm{~m}$ 和 $\left.\mathrm{E}_{2} \mathrm{ym}\right)^{22)}$. 由此可见，中带的海水东浅西深, 沉积环境东部相对稳定, 西部为活动型, 反映白严纪 晚期至始新世洋壳的向北俯冲与陆-陆碰撞造成了地 壳的抬升和新特提斯洋沿雅鲁藏布江缝合带闭合, 地壳抬升首先开始于东侧，闭合的时间从东向西变 新, 海水是从东向西退出的 ${ }^{[34,35]}$.

(2) 新近纪拉分盆地：为乌木隆格津格盆地(图 1)，是沿喀喇昆仑断裂西南侧产生的北西-南东向狭 条状分布的 1 个拉分盆地.

(3)新近纪断陷盆地: 包括札达、普兰、木斯塘、 吉隆、加德满都盆地(图 1). 其中除札达盆地为受为 喀喇昆仑断裂活动影响形成的北西-南东向分布的较 大型断陷盆地外，其余 4 个盆地均为新近纪晚期(约 14 9 Ma 期间)因受南-北向正断层影响，形成的近南-

22) 河北省地质调查院. 西藏 1:25 万日新幅、札达县幅、芫叶马幅区域地质调查报告. 2004

23）西藏自治区地质调查院. 西藏 1:25 万日喀则市幅区域地质调查报告. 2004

24) 成都理工大学地质调查院. 西藏 1:25 万措勤县幅区域地质调查报告. 2003 
北向小型断陷盆地. 上述新近纪盆地均充填了河流洪冲积-扇三角洲-湖泊环境沉积(旦增竹康组、沃马组 和札达群).

该分区的古近纪地层主要为海相沉积, 有柳曲 群、错汇顶群、蹬岗组、郭雅拉组、盐多组、蹬岗混 杂岩、盐多混杂岩、桑麦混杂岩、甲查拉组、基堵拉 组、宗浦组和遮普惹组(图 2). 柳曲群 $\left(\mathrm{E}_{1-2} L\right.$, 厚 2108 $\mathrm{m})$ 为海陆交互相沉积, 在西部巴噶地区下部为黑色、 灰绿色砾岩夹砂岩, 中部为灰紫-紫红色砾岩夹砂岩, 上部为灰绿色、灰褐色岩屑砂岩、含砾砂岩夹砾岩; 在东部拉孜一带为紫红、灰黄和黄绿色复成分砾岩、 砂岩和粘土质粉砂岩等. $\mathrm{E}_{1-2} L$ 含植物化石Juglandites sinuatus, Annona preretieulata, Willisia rentoensis, Rhamnus marginatus, Gindgoites layaminensis, Mahnolia ingleifiedi, Melanourhonea Alaska, Cyclosurus nerulsus及双壳类化石等 ${ }^{18)}$, 时代为古新世-始新世早 期. 错江顶群 $\left(\mathrm{E}_{1-2} \mathrm{C}\right)$ 自下而上划分为达机翁组及日康 巴组. 达机翁组 $\left(\mathrm{E}_{1-2} d j\right.$, 厚 $\left.251 \mathrm{~m}\right)$ 为滨浅海砂岩、含 砾砂岩、泥质粉砂岩夹灰岩, 含有孔虫NummulitesFascillites-Assilina组合 ${ }^{[20]}$, 菊石类Dipoloceras sp., 双壳类Spondylus sp., Septifer sp., 腹足类 Syrnoia sp., Velates tibeticus, Conocezithum sp., Crommium sp. 等 ${ }^{[76]}$, 时代为古新世. 日康巴组 $\left(\mathrm{E}_{2} r\right.$, 厚 $\left.267.8 \mathrm{~m}\right)$ 为 滨浅海砾岩、含砾砂岩夹灰岩及页岩, 含有孔虫 Alveolina-Nummulites 组合, 腹足类Ampullospira cf. acuminata, Cyprcaedia cf. bellireticulata, Mathildia cf. costellata, Architectonica sp., A. vredenburgi, Commium sp.; 双壳类Pseudomiltha sp., Corbula sp., Echinolampas sp., Astarte sp.; 菊石类Dipoloceras sp. 等 ${ }^{[76]}$, 据化石组合时代为古-始新世. 蹬岗组 $\left(\mathrm{E}_{1-2} d\right.$, 厚 $698 \mathrm{~m}$ ) 为灰绿-紫红色页岩、灰绿-黄绿色(含砾)砂 岩夹灰绿色硅质岩, 底部为灰白色砂岩, 为半深海远洋沉积, 含放射虫Amphipternis-Stylotrochus 组合 (早古新世)、Actiuomma-Orbula组合(晚古新世)和 Lithomespilus-Spongotrochus 组合(始新世) $)^{[76]}$. 郭雅拉 组 $\left(\mathrm{E}_{2} g\right.$, 厚 $\left.3982.6 \mathrm{~m}\right)$ 为灰紫-灰绿色中-薄层硅质岩夹 灰紫-灰绿色薄层粉砂岩、页岩、玄武岩及薄层灰岩, 为半深海沉积, 含有孔虫Orbitolites contentinensis, Orbitolites sp., Assilina sp., 时代为始新世 ${ }^{22)}$. 盐多组 $\left(\mathrm{E}_{2} y\right.$, 厚 $\left.1085 \mathrm{~m}\right)$ 为灰紫-灰绿色玄武岩、玄武质角砾
熔岩夹灰绿-紫红色放射虫硅质岩、泥岩、页岩、含 生屑泥晶灰岩, 为半深海相沉积与火山堆积, 含放射 虫Stylotrochus natives, Godia Lenticulatus和有孔虫 Orbitolites contentinensis, Orbitolites sp., Assilina sp., 时代为始新世 ${ }^{22)}$. 蹬岗混杂岩 $\left(\mathrm{E}_{1-2} d g \mathrm{~m}\right)$ 基质为灰色、 灰黑、灰紫色等砂岩、泥页岩、硅质岩的韵律层, 局 部夹玄武岩, 硅质岩中含Acanthocircus eugeneus, Amphipternis clara等丰富的放射虫化石, 时代为古新 世至始新世; 岩块为二叠纪灰色-灰白色夹灰紫色变质灰 岩岩块, 岩块大小不等, 小者几十米, 大者可达 $100 \mathrm{~m}$ 左 右, 以断裂关系镶嵌于基质中 ${ }^{22}$. 盐多混杂岩 $\left(\mathrm{E}_{2} y \mathrm{ym}\right)$ 基 质为灰黑色页岩、灰黑、灰绿色玄武岩夹灰岩和紫红 色具杏仁状构造玄武岩, 玄武岩全岩K-Ar法年龄为 $52.85 \mathrm{Ma}$; 岩块为二叠纪灰岩及晚三叠世硅质岩等, 岩块介于 1 400 m左右, 硅质岩岩块中含有晚三叠世 Orbiculiforma sp.等放射虫化石 ${ }^{22}$. 桑麦混杂岩 $\left(\mathrm{E}_{2} \mathrm{sm}\right)$ 基质为砂岩、泥岩夹灰岩, 为斜坡相沉积, 含有孔虫 Globigerina eugubina, G. fringa, G. sp., Globorotalia sp. 等 ${ }^{22}$, 时代为古新世; 岩块为安山岩、硅质岩、灰 岩. 甲查拉组 $\left(\mathrm{E}_{1} j c\right.$, 厚 $\left.>2764 \mathrm{~m}\right)$ 为青灰色夹灰绿色含 砾凝灰质细砂岩夹青灰色页岩, 在江孜以西的白朗 县江公乡西北一带甲查拉组中鲍马序列十分发育 ${ }^{[77]}$, 总体表现为斜坡相的沉积特征. $\mathrm{E}_{1} j c$ 含沟鞭藻 Apectodinium quinquelatum-Apectodin-iumhy peracanthum 组合、Canningiachinensis-Pal-aeoperidi nium pyrophorum 组合和Cymatiosphaerareticulosa-Samlandia chlamydophora组合, 狍粉Arliaceoipollenites baculatus-Anacolosidites subtrudens 组 合、Aglaoreidiacyclops-Pinuspollenites microinsigis组 合和Elaeangnacites asper-Ilexpollenites iliacus组

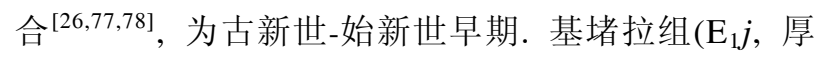
133 293.6 m) 为滨浅海相灰白色含砾石英砂岩夹深灰 色泥晶生物灰岩透镜体, 底部普遍含砾石, 局部为砾 岩, 顶、底部富含褐铁矿, 发育冲洗交错层理及大量 虫管, 产有孔虫Rotalia-Lockhartia带; 介形虫 Urolederis inflata, Brachycythere xizangensis, Bairdia plana等, 时代属古新世丹尼期[26,77]25). 宗浦组 $\left(\mathrm{E}_{1-2} z\right.$, 厚 301 436 m) 为滨浅海相灰色生物碎屑灰岩、砾状灰 岩夹泥灰岩及砂屑灰岩等, 自下而上产有孔虫 Rotalia-Lockhartia带, Keramosphaera带, Actinosi-

25) 成都地质矿产研究所. 西藏 1:25 万聂拉木县幅区域地质调查报告. 2003 
phon带, Miscellanea-Operculina-Daviesina带; 六射珊 瑚 Dendrophyllia, Stylophora, Pocillopora, Kangiliacyathus ${ }^{[26,77,79]}$, 时代属古新世晚丹尼期-坦尼特期. 遮普惹组 $\left(\mathrm{E}_{2} z\right.$, 厚 $\left.478.4 \mathrm{~m}\right)$ 主要为滨浅海相灰绿、紫 红色等杂色粉砂质页岩夹中薄层状泥质灰岩, 底部 为灰色厚层块状有孔虫微晶灰岩(厚约 $25 \mathrm{~m}$ ), 自下向 上产有孔虫Alveolina-Nummulites-Orbitolites 带和 Morozovella spinulosa-Acarinina bullbrooki 带及介形 虫Paracypri smayaensis-Bairdia zongpuxiensis 带和 Phlyctenophora zongpuensis-Semicytheru Subsymmetros 带 ${ }^{[26,77]}$, 时代属始新世. 藏南最高海相层遮普惹 组上部的砂页岩段 (李祥辉等 ${ }^{[80]}$ 曾命名为朋曲组) 顶 部的时代约为 $40 \mathrm{Ma}^{[80]}$, 代表新特提斯海在藏南最终 消亡的时间 ${ }^{[25,80]}$.

该分区的新近纪地层为陆相沉积, 有旦增竹康 组、沃马组、乌郁群和札达群(图 2). 旦增竹康组 $\left(\mathrm{N}_{1} d\right.$, 厚 180 894 m) 为灰红、紫红、粉红夹灰白、灰色和灰 黄色等以红色为主的杂色巨厚层状砾岩, 叠瓦状构 造和冲刷面十分发育, 夹紫红色含砾粉砂质泥岩、含 砾粗砂岩透镜体和灰白色砂质条带, 为洪冲积扇沉 积. 本次在吉隆盆地沃马村南面的旦增竹康组中获 得较丰富的孢粉, 主要有Betula, Ephedra, Pinus, Quercus 和Tsuga等, 据狍粉组合时代为中新世晚期. 沃马组 $(\mathrm{N} w m$, 厚 $398.4 \mathrm{~m}$ )下部和上部均以灰黄、黄褐 砾岩和含砾粗砂岩与灰黄、黄褐、灰黑等杂色粉砂岩、 泥岩互层为主, 中部以灰黄、黄褐夹蓝灰、灰黑等杂 色砂岩、粉砂岩、泥岩为主夹少量砾岩和含砾粗砂岩, 为湖泊夹多层水下扇沉积. $\mathrm{N} w m$ 在吉隆沃马村西北面 约 $2 \mathrm{~km}$ 处的龙骨沟剖面的下部产三趾马等脊椎动物 化石 Hipparion gyizhongensis, Chilotherium xizangensis, Metacervulus capreolinus, Palaeotragus microdon, Gazalla gaudryi, Ochotona gyizhongensis, Hyaena $\mathrm{sp} \cdot{ }^{[81,82]}$. 本次我们在 $\mathrm{N} w m$ 获介形虫 Qaidamuthere vena, Ilyocypris pentanoda, Leucocythere dorsotuberosa, L. rugosa, L. mirabilis, Candoniella xizangensis, C. zadaensis, L. hyalina, L. glabra, I. subdushanensis, Herpetocyprella dvalyi, Leucocytherella sinensis, $L$. trinoda, Leucocytherella trinoda, L. hyalina, L. glabra. 据介形虫化石, 本次在沃马组中自下而上建立了 Qaidamothere-Ilyocypris 组合和Leucocythere- Leucocytherella组合, 时代为中新世晚期-上新世. 施雅风 等 ${ }^{[4]}$ 选择吉隆盆地的塔千沟、加莫沟和龙骨沟 3 条剖 面的沃马组进行了系统的古地磁测年, $\mathrm{N} w m$ 年龄为
7.0 1.67 Ma. 岳乐平等 ${ }^{[83}$ 对龙骨沟沃马组的古地磁 测年为 7.2 3.2 Ma. 乌郁群 $(\mathrm{NW}$, 厚 3672 4290 m)下 部为紫灰色砾岩夹砂岩, 上部为紫灰色砾岩夹含砾 砂岩和砂岩, 部分地区相变为以陆相火山岩为主的 沉积，下部为火山碎屑岩夹含凝灰质岩屑粗粒砂岩、 钙质粉、细砂岩和含砾长石岩屑砂岩, 底部夹泥晶灰 岩, 上部为英安质火山熔岩及少量凝灰质岩屑砂岩. 札达群 $\left(\mathrm{NQp}^{1} \mathrm{Z}\right)$ 包括下部的托林组和上部的香孜组. 托林组 $(\mathrm{N} t$, 厚 $842 \mathrm{~m}$ )分为三段: 一段下部为灰色厚 层砾岩夹砂岩透镜体, 含向上变细的两个沉积韵律, 中部为褐黄色含砾粗砂岩、中粗粒砂岩夹细砾岩, 上 部为厚层砾岩; 二段为黄绿色-灰色中-厚层含砾粗砂 岩、粗砂岩、泥质粉砂岩夹粉砂质泥岩透镜体; 三段 为青灰色-土黄色泥岩和泥质粉砂岩. $\mathrm{N} t$ 为湖泊和扇 三角洲环境沉积, 二段含三趾马、偶蹄类及介形虫化 石 $^{22)}$. $\mathrm{N} t$ 古地磁年龄为 9.5 3.7 $\mathrm{Ma}^{[84]}$, 为中新世晚期上新世. 香孜组 $\left(\mathrm{N}_{2} \mathrm{Qp}^{1} x z\right.$, 厚 $\left.654 \mathrm{~m}\right)$ 为褐黄-褐灰色砾 岩、含砾粗砂岩、粗砂岩夹少量细砂岩和粉砂质泥岩, 为冲洪积扇-河流相沉积, ESR测年为 2.58 2.3 $\mathrm{Ma}^{22)}$, 古地磁年龄为 3.7 2.6 $\mathrm{Ma}^{[84]}$ 和 3.4 2.48 $\mathrm{Ma}^{[85]}$, 时代 为晚上新世-早更新世.

\section{3 恒河地层分区}

包括恒河平原 1 个盆地，为前陆盆地. 古新世和 始新世为海相沉积, 渐新世开始为陆相沉积. 该分区 的沉积地层为含货币虫群、勃固群、穆里组和西瓦利 克群(图 2). 含货币虫群( $\mathrm{E} H$, 厚 $9000 \mathrm{~m}$ ) 以海相碎屑 岩(砂岩、炭质泥岩)和货币虫灰岩为主, 局部夹火山 凝灰岩,含有孔虫Nummulites vredenburgi, N.atacicus 和爬行类化石 ${ }^{[3]}$, 时代为古近纪. 勃固群( $\mathrm{EN} P$, 厚 6000 14000 m) 以陆相碎屑岩为主, 为浅红或紫红色 泥岩、灰绿色粗砂岩和含油岩系, 上部夹流纹岩、安 山岩和凝灰岩 ${ }^{[3]}$. 穆里(Murree)组(EN $m$, 厚 $2500 \mathrm{~m}$ ) 分两段, 下段(Degshia段)为湖相浅红或紫红色泥岩, 上段 (Kasauli段) 为湖-三角洲相粗粒灰绿色粗砂岩, 时代为渐新世至中新世早期 ${ }^{[86]}$. 西瓦利克群 $(\mathrm{NQS}$, 厚 $1800 \mathrm{~m}$ )底部为巨厚层卵石层; 下部为粗砂岩、砂 岩、粉砂岩组成韵律层，向上为蓝灰色粗砂岩; 中部 是砾岩夹松散的砂岩层; 上部为灰色硬砂质含云母 砂岩. NQS下部年龄为 $14.6 \mathrm{Ma}^{[86,87]}$. NQS 时代为中新 世中期-第四纪早期，为前陆盆地磨拉石建造，表现 出向上变粗变厚、向南变细变新的变化趋势, 并有盆 
地西部先沉积的特征.

\section{6 讨论与结论}

通过上述对青藏高原及周缘古近纪-新近纪地层 区划讨论(图 1), 以及对各个地层分区残留盆地类型、 形成构造背景、岩石地层序列及其沉积特征、地层接 触关系(图 2)、时代确定依据与沉积演化过程的描述, 本文在潘桂棠等 ${ }^{[2]}$ 和李廷栋 ${ }^{[88}$ 对青藏高原三大隆升 阶段(俯冲碰撞隆升, 汇聚挤压隆升, 均衡调整隆升) 划分的基础上, 进一步将青藏高原新生代的隆升及 其沉积响应细分为如下 8 个亚阶段.

\section{1 俯冲碰撞隆升阶段(65 34 Ma)}

为古新世-始新世隆升阶段, 细分为 3 个亚阶段:

(1) 65 56 Ma. 印度与欧亚板块初始碰撞, 表现 为冈底斯岩浆弧内发育的古近纪同碰撞型林子宗火 山岩(底部年龄为 64.8 64.4 $\mathrm{Ma}^{[67,69]}$ ) 和其南侧以柳曲 群和错江顶群为代表的古近纪海陆过渡-滨浅海磨拉 石沉积均与下伏白严统呈角度不整合接触, 指示印 度与欧亚沿雅江初始碰撞发生在古新世初(约 $65 \mathrm{Ma}$ ). 随初始碰撞的发生, 青藏高原大型周缘前陆盆地和 压陷盆地形成. 周缘前陆盆地是恒河平原盆地 ${ }^{[3]}$; 压 陷盆地是成都盆地 ${ }^{[89,90]}$ 和塔里木盆地 ${ }^{[5]}$ (图 1); 上述 盆地内的古新统与下伏的上白严统整合, 在古新统 内无明显沉积缺失(图 2), 说明印度与欧亚在约 65 $\mathrm{Ma}$ 初始碰撞后的古新世期间的汇聚不太剧烈.

(2) 56 45 Ma. 印度与欧亚板块碰撞高峰期, 藏 南新特提斯残留海逐渐消亡, 表现在沿雅江两侧东 西向分布的海相地层, 海水东浅西深 ${ }^{[27] 24)}$, 反映碰撞 和地壳抬升自东向西迁移 ${ }^{[34,35]}$. 随着全面碰撞的发 生, 高原北缘兰州-西宁压陷盆地和柴达木-可可西 里-美塘压陷盆地形成并接受沉积. 兰州、西宁、柴达 木、可可西里和㒸塘盆地开始接受沉积的时间分别为 $58 \mathrm{Ma}\left(\mathrm{E}_{1-2} x\right)^{[45]}, 52.5 \mathrm{Ma}\left(\mathrm{E}_{1-2} x\right)^{[47]}, 53.47 \mathrm{Ma}\left(\mathrm{E}_{2} l\right)^{[39]}$, $52 \mathrm{Ma}\left(\mathrm{E}_{2} t\right)^{[23]}$ 和 $57 \mathrm{Ma}\left(\mathrm{E}_{1-2} n\right)^{[20]}$, 盆地内新生代的初 始沉积均以陆源粗碎屑的砾岩和含砾粗砂岩开始(图 2), 是碰撞的沉积响应. 另外, 高原东缘的玉树一川西藏东走滑拉分盆地在该阶段后期开始形成, 如贡觉 盆地新生代地层中的 7 个火山岩 $\mathrm{K}-\mathrm{Ar}$ 年龄为 40.8 $46.2 \mathrm{Ma}^{[62,63]}$.

(3) 45 34 Ma. 印度与欧亚板块全面碰撞 ${ }^{[1,91]}$ 和
藏南新特提斯残留海消亡 ${ }^{[80]}$, 约 $40 \mathrm{Ma}$ 海水从藏南东 部的岗巴-定日一带全部退出 ${ }^{[80]}$, 估计从藏南西部(萨 嘎以西)退出的时间约 $38 \mathrm{Ma}$ 左右, 藏南新特提斯残 留海的消亡从沉积盆地演化上标志印度与欧亚板块 完成了在藏南沿雅江的全面碰撞. 钟大类等 ${ }^{[91]}$ 和孙 鸿烈等 ${ }^{[1]}$ 将 45 38 Ma定为印度与欧亚板块碰撞的高 峰期. 随着全面碰撞的完成, 高原东缘新的走滑拉分 盆地形成, 如囊谦和下拉秀盆地新生代地层火山岩 夹层 ${ }^{40} \mathrm{Ar}{ }^{39} \mathrm{Ar}$ 年龄为 $38 \mathrm{Ma}^{[60]}$, 指示盆地内沉积物 初始形成期应大于 $38 \mathrm{Ma}$, 火山活动发生在碰撞构造 环境中, 受陆内水平剪切-走滑断裂带控制. 此阶段 因全面完成碰撞而导致发生在冈底斯一带的初始隆 升事件被称为冈底斯运动 ${ }^{[92,93]}$. 约 $40 \mathrm{Ma}$ 喜马拉雅初 始隆升, 冈底斯继续隆起. 其隆升证据是在此期间喜 马拉雅完全脱离沉积, 处于隆起剥蚀阶段(图 2); 冈 底斯带在约 36 34 Ma期间存在区域不整合面和沉积 缺失, 如秋乌组和大竹卡组、帕那组和日贡拉组之间 的不整合(图 2). 锆石裂变径迹年龄也记录了喜马拉 雅 43 36 Ma存在岩石抬升事件 ${ }^{[94,95]}$. 磷灰石裂变径 迹测年及其热模拟均揭示出 45 35 Ma冈底斯构造带 的快速冷却剥露 ${ }^{[96]}$. 此阶段高原从全面碰撞向陆内 隆升造山阶段过渡.

\section{2 陆内汇聚挤压隆升阶段(34 13 Ma)}

为渐新世-中新世早期隆升阶段, 细分为 3 个亚 阶段:

(1) 34 25 Ma. 此阶段的隆升仍发生在冈底斯, 隆升时段集中分布在 34 30 Ma. 表现在沿冈底斯带 分布的日贡拉组砾岩. 随高原差异隆升, 在高原东北 缘出现了临夏-循化新的压陷盆地(图 1). 临夏盆地开 始沉积的时间为 $29 \mathrm{Ma}(\mathrm{EN} t)^{[97,98]}$, 循化盆地当时与 临夏盆地相连, 盆内沉积充填序列基本一致, 为一统 一的压陷盆地 ${ }^{[49]}$.

(2) 25 20 Ma. 沿冈底斯南缘广布大竹卡组砾岩. 大竹卡组砾岩主要是巨厚的山地洪冲积扇和山区河 流相堆积, 沿冈底斯带南缘东西向分布长约 1500 $\mathrm{km}^{[20]}$; 大竹卡组呈东西向窄长带状分布也指示了其 南部的喜马拉雅带当时已隆起, 阻档了大竹卡组的 向南分布. 可可西里-沱沱河初始隆升. 可可西里-沱 沦河隆升的证据主要来自雅西措组与五道梁组间的 角度不整合(图 2), 并使盆地内的古近纪沉积物(沱沱 河组和雅西措组)遭受抬升变形 ${ }^{[23]}$. 约 $23 \mathrm{Ma}$ (渐新世 
与中新世之交)时高原整体隆升, 表现在约 $23 \mathrm{Ma}$ 几 乎遍布全高原及周边的沉积缺失和不整合面(图 2), 此次隆升事件被称为喜马拉雅运动 ${ }^{[92,93]}$. 此阶段另 一显著的沉积响应是塔里木海相地层在约 $23 \mathrm{Ma}$ 时 结束, 表现在塔里木盆地含海相生物的渐新世地层 $\mathrm{E}_{3} b$ 在约 $23 \mathrm{Ma}$ 时被含陆相生物为主的中新世地层 $\mathrm{N}_{1} k$ 平行不整合覆盖 ${ }^{[5,6]}$.

(3) 20 13 Ma. 喜马拉雅-冈底斯-西昆仑快速隆 升，隆升时段集中分布在 22 16 Ma. 上述地区除冈 底斯带零星分布一些山间断陷盆地沉积外, 普遍缺 失沉积, 是被剥蚀的隆起区(图 2). 喜马拉雅该阶段 的隆升有大量报道, 如印度西北部特提斯喜马拉雅 Tso Morari推覆体在大约 $20 \mathrm{Ma}$ 左右结晶岩席推覆体 再次发生在浅层次脆性域中的向上楔冲挤出抬升 ${ }^{[95]}$; 以喜马拉雅主中央逆冲断层为代表的系列逆冲推覆 作用主要发生在 23 20 Ma左右 ${ }^{[2,99 ~ 101]}$; 逆冲推覆引 起沿喜马拉雅构造带强烈的地壳加厚, 导致下地壳部 分熔融形成沿喜马拉雅带广布的淡色花岗岩的锆石 $\mathrm{U}-\mathrm{Pb}$ 年龄集中分布于 22 19 $\mathrm{Ma}$ ，少量延续到 17 16 和 14 12 $\mathrm{Ma}^{[102]}$; 由强烈抬升引发的藏南拆离系的活 动时间一般被限定为 $22 \sim 14 \mathrm{Ma}^{[101,103,104]}$. 冈底斯隆 升的证据如Harrison等 ${ }^{[105]}$ 报道曲水岩体 20 18 Ma间 快速冷却, 剥蚀速率大于 $2 \mathrm{~mm} / \mathrm{a}$, 这一时期正是冈 底斯构造带大规模向南仰冲并控制南侧沿雅江分布 的大竹卡组砾岩沉积 ${ }^{[105,106]}$. 西昆仑存在 22.7 和 16 $\mathrm{Ma}$ 两期强构造岩浆活动期 ${ }^{[107]}$, 是强烈隆升的结果. 这一时期也是高原东部一系列走滑断裂活动与拉分 盆地充填活跃期 ${ }^{[1]}$. 高原周缘压陷盆地和高原内的芫 塘、可可西里-沱沱河、柴达木等大型压陷盆地进入 沉积充填活跃期, 出现了高原及邻区的最大湖泊扩 张期, 如塔里木盆地南部的 $\mathrm{N}_{1} k$, 柴达木盆地的 $\mathrm{N}_{1} y$, 芫塘盆地的 $\mathrm{EN} k$, 可可西里盆地的 $\mathrm{N}_{1} w$ 和成都盆地的 $\mathrm{N} l s$ 等.

\section{3 陆内均衡调整隆升阶段(13 Ma 以来)}

为中新世中期-第四纪隆升阶段, 细分为 2 个亚 阶段:

(1) 13 5 Ma (中新世晚期). 喜马拉雅-冈底斯持 续隆升，表现在该地区整体处在无沉积的剥蚀状态 (图 2). 由于持续隆升, 藏南南北向断陷盆地形成, 如 吉隆、木斯塘、普兰盆地和羊八井地堑等(图 1). 青 藏高原南北向断陷盆地的形成被认为是高原隆升到
足够高度开始垮塌的标志 ${ }^{[105,108,109]}$. 这一时期另一显 著的隆升区域是西昆仑-喀喇昆仑-芫塘-可可西里-沱 沱河地区, 其沉积响应体现在该区域的沉积缺失与 区域性不整合面的广布(图 2), 如西昆仑和喀喇昆仑 一带零星分布的 $\mathrm{N}_{1} p$ 底部的角度不整合与沉积缺失, 芫塘地区 $\mathrm{N} s$ 与下伏地层 $\mathrm{EN} k$ 或 $\mathrm{E}_{3} d$ 间的沉积缺失与不 整合, 可可西里-沱沱河地区 $\mathrm{N}_{1} w$ 与 $\mathrm{N}_{2} q$ 间的沉积缺 失与不整合等. 综合已有基岩裂变径迹年代学资料, 西昆仑表现出 10 8 Ma的强抬升剥露期 ${ }^{[35,110,111]}$. 8 Ma以前高原周缘压陷盆地仍处在湖泊拓展最大期沉 积阶段; 但 $8 \mathrm{Ma}$ 以后高原及邻区大型湖泊进入湖退 期. 但约在 7 5 Ma期间, 藏南断陷盆地和川西-藏东滇西走滑拉分盆地发育进入鼎盛期. 藏南的吉隆、木 斯塘、普兰、札达、巴噶、郭拉-乌郁等盆地均进入 到湖泊拓展最大期沉积, 如这一时期在上述盆地发 育的沃马组、托林组和宗当组等; 川西-藏东-滇西地 区分布的走滑拉分盆地也发展到鼎盛阶段，以湖和 扇三角洲相沉积充填为主, 如该时期发育的昌台组 和拉屋拉组(图 2).

(2) $5 \mathrm{Ma}$ 以来 (上新世以来). 高原周缘压陷盆地 沉积萎缩. 高原内部表现为该阶段广泛分布的不整 合面与沉积缺失. 高原周缘压陷盆地表现为向上变 粗序列的普遍出现, 反映了大型湖泊的萎缩, 细粒湖 泊沉积让位于三角洲与水下扇沉积, 如塔里木叶城 一带的阿图什组、酒泉-张掖盆地的疏勒河组上部、 柴达木盆地的狮子沟组上部、西宁盆地的临夏组、恒 河盆地的西瓦利克群上部等(图 2). 综合全高原已有 裂变径迹年代学资料, 均表现出 $5 \mathrm{Ma}$ 以来遍布高原 的强抬升剥露期 ${ }^{[35]}$.

3.5 Ma以来为高原整体快速隆升和高原周缘巨 砾岩堆积期。该阶段隆升表现为高原周缘山麓冲洪 积扇砾岩堆积的广泛分布和砾岩堆积与下伏地层间 的不整合接触 ${ }^{[4,93,112]}$. 如西昆仑山前叶城一带的西域 组、酒泉-张掖一带的玉门组、临夏-循化-同仁-贵德 一带的积石组、昆仑山哑口的昆仑组、成都盆地西缘 的大邑组、札达盆地的香孜组和喜马拉雅山系南侧的 西瓦利克群等(图 2). 约 $3.5 \mathrm{Ma}$ 左右高原周缘巨砾岩 堆积的大致同期出现，是该期高原整体隆升在沉积 上的直接响应。该阶段对高原整体隆升的另一沉积 响应是高原周缘压陷盆地和高原内部大型湖泊解体 消亡，表现在原大型湖泊环境细粒沉积的中止，并被 
三角洲平原、扇三角洲、河流及山麓冲洪积扇环境砾 岩、含砾粗砂岩等粗碎屑为主的沉积物所替代. 发生
在约 3.5 和 $2.6 \mathrm{Ma}$ 的高原整体隆升事件分别被称为青 藏运动 $A$ 幕和 $B$ 幕 ${ }^{[92,93,112]}$.

致谢中国地质调查局、成都地质矿产研究所、西安地质矿产研究所和有关院校、省市和自治区地质调查研究院提 供了青藏高原及邻区 $1: 25$ 万区域地质填图资料, 审稿人提出了宝贵意见, 在此谨表谢意.

\section{参考文献}

1 孙鸿烈, 郑度. 青藏高原形成演化与发展. 广州: 广东科技出版社, 1998. 1-350

2 潘桂棠, 王培生, 徐耀荣, 等. 青藏高原新生代构造演化. 北京: 地质出版社, 1990. 1-165

3 潘桂棠, 丁俊, 姚东生, 等. 青藏高原及邻区地质图(1:500000)及说明书. 成都: 成都地图出版社, 2004. 1-133

4 施雅风, 李吉均, 李丙元, 等. 青藏高原晚新生代隆升与环境变化. 广州: 广东科技出版社, 1998. 1-463

5 蒋显庭, 周维芬, 林树鎜. 新疆地层及介形虫化石. 北京: 地质出版社, 1995. 1-577

6 郝诒纯, 曾学鲁, 李汉敏. 塔里木盆地西部晚白严世-第三纪地层及有孔虫. 见: 地层古生物专辑( I ). 地球科学一武汉地质学院 学报, 1982, 17: 1-161

7 侯佑堂, 宋之琛, 何俊德, 等. 关于中国新生代地层的划分与对比问题(中国新生代地层划分对比说明书). 见: 中国科学院南京地质 古生物研究所, 编. 中国各纪地层对比表及说明书. 北京: 科学出版社, 1982. 286-299

8 李云通，等. 中国地层一一中国的第三系. 北京: 地质出版社, 1984. 272-341

9 万晓樵. 西藏白严纪-早第三纪有孔虫与特提斯-喜马拉雅海的演化. 微体古生物学报, 1990, 7: 169-186

10 云南省地质矿产局. 云南省岩石地层. 武汉: 中国地质大学出版社, 1996. 1-366

11 西藏自治区地质矿产局. 西藏自治区岩石地层. 武汉: 中国地质大学出版社, 1997. 1-302

12 青海省地质矿产局. 青海省岩石地层. 武汉: 中国地质大学出版社, 1997. 1-388

13 新疆维吾尔自治区地质矿产局. 新疆维吾尔自治区岩石地层. 武汉: 中国地质大学出版社, 1999. 1-430

14 甘肃省地质矿产局. 甘肃省岩石地层. 武汉: 中国地质大学出版社, 1997. 1-288

15 四川省地质矿产局. 四川省岩石地层. 武汉: 中国地质大学出版社, 1997. 1-417

16 Gautam P, Roesler W. Depositional chronology and fabric of Siwalik Group sediments in Central Nepal from magnetostratigraphy and magnetic anisotropy. J Asian Earth Sci, 1999, 17: 659-682

17 王鸿祯, 史晓颖, 王训练, 等. 中国层序地层研究. 广州: 广东科技出版社, 2000. 1-457

18 Hoorn C, Ohja T, Quade J. Palynological evidence for vegetation development and climatic change in the Sub-Himalayan Zone (Neogene, Central Nepal). Palaeogeogr Palaeoclimatol Palaeoecol, 2000, 163: 133-161

19 于庆文, 李长安, 古风宝, 等. 青藏高原东北缘新生代隆升-沉积-气候演化及其耦合. 武汉: 中国地质大学出版社, 2001. 1一 123

20 赵政璋, 李永铁, 叶和飞, 等. 青藏高原地层. 北京: 科学出版社, 2001. 1-542

21 周志毅, 赵治信, 胡兆珣, 等. 塔里木盆地各纪地层. 北京: 科学出版社, 2001. 1-359

22 史基安, 陈国俊, 王琪. 塔里木盆地西部层序地层与沉积、成岩演化. 北京: 科学出版社, 2001. 1-253

23 刘志飞, 王成善, 伊海生, 等. 可可西里盆地新生代沉积演化历史重建. 地质学报, 2001, 75: 250-258

24 Robinson D M, DeCelles P G, Patchett P J, et al. The kinematic evolution of the Nepalese Himalaya interpreted from Nd isotopes. Earth Planet Sci Lett, 2001, 192: 507-521

25 李国彪, 万晓樵. 藏南岗巴-定日地区始新世微体化石与特提斯的消亡. 地层学杂志, 2003, 27: 99-108

26 李国彪, 万晓樵, 刘文灿. 西藏南部古近纪微体古生物及盆地演化特征. 北京: 地质出版社, 2004. 1- 152

27 丁林. 西藏雅鲁藏布江缝合带古新世深水沉积和放射虫动物群的发现及对前陆盆地演化的制约. 中国科学 D辑: 地球科学, 2003, 33: $47-58$

28 殷鸿福, 张克信, 陈能松, 等. 中华人民共和国区域地质调查报告(比例尺 1:250000), 冬给措纳湖幅(I47C001002). 武汉：中国地质 大学出版社, 2003. 1-457

29 Jin X C, Wang J, Chen B W, et al. Cenozoic depositional sequences in the piedmont of the west Kunlun and their paleogeographic and tectonic implications. J Asian Earth Sci, 2003, 21: 755-765

30 王乃文, 何希贤. 古近纪 - 新近纪. 见: 汪啸风, 陈孝红, 等, 编. 中国各地质时代地层划分与对比. 北京: 地质出版社, 2005. 487一 558

31 Wang Y, Deng T, Biasatti D. Ancient diets indicate significant uplift of southern Tibet after ca. 7 Ma. Geology, 2006, 34: 309-312 
32 李荣社，计文化，杨永成，等. 昆仑山及邻区地质. 北京：地质出版社, 2008. 1-400

33 Wang C S, Zhao X X, Liu Z F, et al. Constraints on the early uplift history of the Tibetan Plateau. Proc Natl Acad Sci USA, 2008,105: 4987 $-4992$

34 张克信, 王国灿, 陈奋宁, 等. 青藏高原古近纪-新近纪隆升与沉积盆地分布耦合. 地球科学一一国地质大学学报, 2007, 32: 583一 597

35 张克信, 王国灿, 曹凯, 等. 青藏高原新生代主要隆升事件: 沉积响应与热年代学记录. 中国科学 D 辑: 地球科学, 2008, 38: 1575一 1588

36 李思田, 解习农, 王华, 等. 沉积盆地分析基础与应用. 北京: 高等教育出版社, 2004. 1-410

37 Zheng H B, Christopher M, An Z S, et al. Pliocene uplift of the northern Tibetan Plateau. Geology, 2000, 28: 715—718

38 潘裕生, 文世宣, 孙东立. 喀喇昆仑山-昆仑山地区地质演化. 北京: 科学出版社, 2000. 1-525

39 宋春晖. 青藏高原北缘新生代沉积演化与高原构造隆升过程. 博士学位论文. 兰州: 兰州大学, 2006. 1-326

40 方小敏, 赵志军, 李吉均, 等. 祁连山北缘老君庙背斜晚新生代磁性地层与高原北部隆升. 中国科学 D 辑: 地球科学, 2004, 34: 97一 106

41 青海石油管理局勘探开发研究院, 中国科学院南京地质古生物研究所. 柴达木盆地第三纪介形虫动物群. 南京: 南京大学出版社, 1988. $1-190$

42 唐伦和, 狄恒恕. 柴达木盆地轮藻化石. 北京: 科学技术文献出版社, 1991. 1-299

43 邓涛, 王晓鸣. 柴达木盆地晚中新世三趾马化石. 古脊椎动物学报, 2004, 42: 316一-333

44 常宏, 方小敏, 安芷生, 等. 索尔库里盆地中-上新世地层特征及其环境意义. 海洋地质与第四纪地质, 2001, 21: 107一111

45 岳乐平, 邱占祥, 颕光普, 等. 兰州盆地永登剖面记录的第三纪沉积环境. 沉积学报, 2003, 21: 683-687

46 邱占祥, 谢骏义, 阎德发. 甘肃东乡几种早中新世哺乳动物化石. 古脊椎动物学报, 1990, 28: 9-24

47 Dai S, Fang X M, Dupont-Nivet G, et al. Magnetostratigraphy of Cenozoic sediments from the Xining Basin: Tectonic implications for the northeastern Tibetan Plateau. J Geophys Res, 2006, 111(B11): 1-19

48 李传㬉, 邱铸鼎. 青海西宁盆地早中新世哺乳动物化石. 古脊椎动物学报, 1980, 18: 198-214

49 刘少峰, 张国伟, Heller P L. 循化-贵德地区新生代盆地发育及其对高原增生的指示. 中国科学 D 辑: 地球科学, 2007, 37(增刊 I ): $235-248$

50 陆济璞, 等. 中华人民共和国区域地质调查报告(比例尺 $1: 250000)$, 布诺错幅(I45C002002). 武汉: 中国地质大学出版社, 2010

51 张克银, 牟泽辉, 朱宏权, 等. 西藏伦坡拉盆地成藏动力学系统分析. 新疆石油地质, 2000, 21: 93-97

52 陈国荣，等. 中华人民共和国区域地质调查报告(比例尺 1:250000), 班戈县幅(H46C001001). 北京：地质出版社, 2010

53 曾庆高, 等. 中华人民共和国区域地质调查报告(比例尺 1:250000), 日干配错幅(I45C004002). 武汉：中国地质大学出版社, 2010

54 曲永贵, 等. 中华人民共和国区域地质调查报告(比例尺 1:250000), 多巴区幅(H45C001004). 武汉: 中国地质大学出版社, 2010

55 陈铭荣，等. 中华人民共和国区域地质调查报告(比例尺 1:250000), 玉帽山幅(I45C001003). 北京:地质出版社, 2010

56 王永胜, 等. 中华人民共和国区域地质调查报告(比例尺 1:250000), 昂达尔错幅(I45C004004). 武汉: 中国地质大学出版社, 2010

57 朱同兴, 等. 中华人民共和国区域地质调查报告(比例尺 1:250000), 黑虎岭幅(I45C002003). 武汉: 中国地质大学出版社, 2010

58 宋春晖, 高东林, 方小敏, 等. 青藏高原昆仑山垭口盆地晚新生代高精度磁性地层及其意义. 科学通报, 2005, 50: 2145一-2154

59 朱迎堂, 等. 中华人民共和国区域地质调查报告(比例尺 $1: 250000$ ), 可可西里湖幅(I46C001001). 武汉: 中国地质大学出版社, 2010

60 周江羽, 王江海, 尹安, 等. 青藏东北缘早第三纪盆地充填的沉积型式及构造背景一以囊谦和下拉秀盆地为例. 沉积学报, 2002, 20: $85-91$

61 王世锋, 伊海生, 王成善. 青藏高原东部囊谦第三纪盆地沉积构造征. 北京大学学报(自然科学版), 2002, 38: 109一114

62 李忠雄, 陈智梁, 李修忠, 等. 青藏高原东部贡觉盆地新生代火山岩的 K-Ar 稀释法年龄. 地球科学一一国地质大学学报, 2004, 29: $971-975$

63 李忠雄, 陈智梁, Studnicke C, 等. 青藏高原东部贡觉盆地新生代火山岩特征及其构造意义. 地球学报, 2006, 27: 297一-302

64 张会化, 贺怀宇, 王江海, 等. 西藏芒康盆地内高钾火山岩 ${ }^{40} \mathrm{Ar}{ }^{39} \mathrm{Ar}$ 的年代学和地球化学研究. 中国科学 $\mathrm{D}$ 辑: 地球科学, 2004, 34: $24-34$

65 刘耕斌. 川西高原白严纪狍粉组合的发现及其意义. 微体古生物学报, 1999, 16: 54-60

66 中国科学院青藏高原科学考察队. 西藏地层. 北京: 科学出版社, 1984. 1-399

67 周肃, 莫宣学, 董国臣, 等. 西藏林周盆地林子宗火山岩 ${ }^{40} \mathrm{Ar} /{ }^{39} \mathrm{Ar}$ 年代格架. 科学通报, 2004, 49: 2095-2103

68 李皓扬, 钟孙霖, 王彦斌, 等. 藏南林周盆地林子宗火山岩的时代、成因及其地质意义: 锆石 U-Pb 年龄和 $\mathrm{Hf}$ 同位素证据. 岩石学报, 2007, 23: 493-500

69 梁银平, 朱杰, 次邛, 等. 青藏高原冈底斯带中部朱诺地区林子宗群火山岩锆石 U-Pb 年龄和地球化学特征. 地球科学一一国地质 
大学学报, 2010, 35: 1-13

70 周肃, 方念乔, 董国臣, 等. 西藏林子宗群火山岩的氩-氩同位素测年. 矿物岩石学地球化学杂志, 2001, 20: 317一 319

71 李才, 朱志勇, 迟效国. 藏北改则地区鱼鳞山组火山岩同位素年代学. 地质通报, 2002, 21: 732-734

72 石和, 马润则, 刘登忠, 等. 西藏措勤地区的中新世布嘎寺组. 成都理工大学学报(自然科学版), 2005, 32: 470-473

73 Spicer R A, Harris N B W, Widdowson M, et al. Constant elevation of southern Tibet over the past 15 million years. Nature, 2003, 421: 622 $-624$

74 陈贺海, 汉景泰, 丁仲礼, 等. 藏南乌郁盆地晚新生代沉积序列的时代及其区域构造意义. 中国科学 D 辑: 地球科学, 2007, 37: 1617 $-1624$

75 李国彪, 万晓樵，其和日格，等. 西藏岗巴-定日地区始新世化石碳酸岩盐微相及沉积环境. 中国地质, 2002, 29: 401一 406

76 张振利, 田立富, 范永贵, 等. 萨嘎县幅、桑桑区幅、吉隆县幅地质调查新成果及主要进展. 地质通报, 2004, 23: 427一 432

77 刘文灿, 万晓樵, 梁定益, 等. 江孜县幅、亚东县幅地质调查新成果及主要进展. 地质通报, 2004, 23: 444-450

78 魏玉帅, 王成善, 李祥辉, 等. 藏南古近纪甲查拉组物源分析及其对印度-欧亚大陆碰撞启动时间的约束. 矿物岩石, 2006, 26: 46一 55

79 赵文金, 万晓樵. 西藏特提斯演化晚期生物古海洋事件. 北京: 地质出版社, 2003. 1-116

80 李祥辉, 王成善, 胡修棉, 等. 朋曲组——西藏南部最高海相层位一个新的地层单元. 地层学杂志, 2000, 24: 243-248

81 计宏祥, 许钦琦, 黄万波. 西藏吉隆沃马公社三趾马动物群. 西藏古生物(一). 北京: 科学出版社, 1980. 18一22

82 黄万波, 计宏祥, 陈万勇, 等. 西藏吉隆、布隆盆地的上新世地层. 西藏古生物(一). 北京: 科学出版社, 1980. 4-17

83 岳乐平, 邓涛, 张睿, 等. 西藏吉隆一一沃马盆地龙骨沟剖面古地磁年代学及喜马拉雅山抬升记录. 地球物理学报, 2004, 47: 10091016

84 王世锋, 张伟林, 方小敏, 等. 藏西南札达盆地磁性地层学特征及其构造意义. 科学通报, 2008, 53: 676一 683

85 孟宪刚, 朱大岗, 邵兆刚, 等. 西藏西部札达盆地早更新世香孜组沉积特征和时代一一对青藏高原第四系底界的约束. 地质通报, 2005, 24: 536-541

86 徐叔鹰. 大陆碰撞与成山过程一以印度河上游地区为例. 苏州铁道师院学报(自然科学版), 1995, 12: 47-54

87 向芳, 王成善, 朱利东. 青藏高原南缘新生代磨拉石的沉积特征. 成都理工学院学报, 2002, 29: 614-619

88 李廷栋. 青藏高原隆升的过程和机制. 地球学报一一中国地质科学院院报, 1995, 16: 1-9

89 李元林. 大溪砾岩及其时代归属. 成都理工学院学报, 1995, 22: 11-14

90 曾宜君, 杨学俊, 李云泉, 等. 川西前陆盆地南部中新生代砾岩的构造意义. 四川地质学报, 2004, 24: 198一201

91 钟大㐘, 丁林. 青藏高原的隆起过程及其机制探讨. 中国科学 D 辑: 地球科学, 1996, 26: 289-295

92 施雅风, 李吉均, 李炳元, 等. 晚新生代青藏高原的隆升与东亚环境变化. 地理学报, 1999, 54: 10-20

93 李吉均, 方小敏, 潘保田, 等. 新生代晚期青藏高原强烈隆起及其对周边环境的影响. 第四纪研究, 2001, 21: 381一-391

94 Zeitler P K. Cooling history of the NW Himalaya, Pakistan. Tectonics, 1985, 4: 127-151

95 Schlup M, Carter A, Cosca M, et al. Exhumation history of eastern Ladakh revealed by ${ }^{40} \mathrm{Ar} /{ }^{39} \mathrm{Ar}$ and fission track ages: The Indus River-Tso Morari transect, NW Himalaya. J Geol Soc, 2003, 160: 385-399

96 Wang Y, Zhang X M, Sun L X, et al. Cooling history and tectonic exhumation stages of the south-central Tibetan Plateau (China): Constrained by ${ }^{40} \mathrm{Ar} /{ }^{39} \mathrm{Ar}$ and apatite fission track thermochronology. J Asian Earth Sci, 2007, 29: 266-282

97 方小敏, 李吉均, 朱俊杰, 等. 甘肃临夏盆地新生代地层绝对年代测定与划分. 科学通报, 1997, 42: 1457-1471

98 方小敏, 宋春晖, 高军平, 等. 青藏高原东北缘晚新生代哺乳动物化石的磁性地层学. 科学通报, 2002, 47: 1824一1828

99 Parrish R R, Hodges K V. Miocene ( $22 \pm 1 \mathrm{Ma})$ metamorphism and two stage thrusting in the Greater Himalayan sequence, Annapurna Sanctuary, Nepal. Geol Soc Amer Abstract Program, 1993, 25: 174

100 Coleman M E. U-Pb constraints on Oligocene-Miocene deformation and anatexis within the central Himalaya, Marsyandi valley, Nepal. Amer J Sci, 1998, 298: 553-571

101 Harrison T M, Copeland P, Kidd W, et al. Activation of the Nyainqentanghla Shear Zone: Implications for uplift of the southern Tibetan Plateau. Tectonics, 1995, 14: 658-676

102 Searle M P, Godin L. The south Tibetan detachment and the Manaslu leucogranite: A structural reinterpretation and restoration of the Annapurna-Manaslu Himalaya, Nepal. J Geol, 2003, 111: 505-523

103 Hodges K V, Bowring S, Davidek K, et al. Evidence for rapid displacement on Himalayan normal faults and the importance of tectonic denudation in the evolution of mountain ranges. Geology, 1998, 26: 483-486

104 Burchfiel B C, Chen Z, Hodges K V, et a1. The south Tibet detachment system, Himalayan orogen: Extension contemporaneous with and parallel to shortening in a collisional mountain belt. Special Paper-Geol Soc Amer, 1992, 269: 1—41 
105 Harrison T M, Copeland P, Kidd W S, et al. Raising Tibet. Science, 1992, 255: 1663-1670

106 Yin A, Harrison T M, Ryerson F J, et al. Tertiary structural evolution of the Gangdese thrust system, southeastern Tibet. J Geophys Res-Solid Earth, 1994, 99(B9): 18175-18201

107 毕华，王中刚，王元龙，等. 西昆仑造山带构造-岩浆演化史. 中国科学 D 辑：地球科学, 1999, 29: 398一406

108 Yin A, Kapp P, Murphy M A, et al. Significant late Neogene east-west extension in northern Tibet. Geology, 1999, 27: 787-790

109 Blisniuk P M, Hacker B R, Glodny J, et al. Normal faulting in central Tibet since at least 13.5 Myr ago. Nature, 2002, 417: 911—913

110 Wang E, Wan J, Liu J. Late Cenozoic geological evolution of the foreland basin bordering the west Kunlun range in Pulu area: Constrain on timing of uplift of northern margin of the Tibet Plateau. J Geophys Res, 2003, 108(B8): 1-15

111 王彦斌，王永，刘训，等. 天山、西昆仑山中、新生代幕式活动的磷灰石裂变径迹记录. 中国区域地质, 2001, 20: 94一 99

112 李吉均, 方小敏. 青藏高原隆起与环境变化研究. 科学通报, 1998, 43: 1569-1574 